\title{
Seismic markers of the Messinian salinity crisis in the deep Ionian Basin
}

\author{
Angelo Camerlenghi $^{1}$ | Anna Del Ben ${ }^{2}$ | Christian Hübscher ${ }^{3}$ | Edy Forlin ${ }^{1}$ | \\ Riccardo Geletti $^{1}$ | Giuseppe Brancatelli ${ }^{1}$ | Aaron Micallef ${ }^{4,5}$ | Marco Saule ${ }^{1,2}$ | \\ Lorenzo Facchin ${ }^{1}$
}

${ }^{1}$ National Institute of Oceanography and Applied Geophysics OGS, Trieste, Italy

${ }^{2}$ Department of Mathematics and Geosciences, University of Trieste, Trieste, Italy

${ }^{3} \mathrm{CEN}$ - Center for Earth System Research and Sustainability, Institute of Geophysics, University of Hamburg, Hamburg, Germany

${ }^{4}$ Marine Geology and Seafloor Surveying, Department of Geosciences, University of Malta, Msida, Malta

${ }^{5}$ GEOMAR - Helmholtz Centre for Ocean Research Kiel, Kiel, Germany

\section{Correspondence}

Angelo Camerlenghi, National Institute of Oceanography and Applied Geophysics OGS, Trieste, Italy.

Email: acamerlenghi@inogs.it

Funding information

Directorate-General for Research and Innovation, Grant/Award Number: ERC Starting Grant n677898 (MARCAN) and Marie Curie Career Integration Grant PCIG13-GA-201; Universität Hamburg, Grant/Award Number: RV Meteor Expedition M142/2; European Cooperation in Science and Technology, Grant/Award Number: COST Action CA15103

\begin{abstract}
We conduct the seismic signal analysis on vintage and recently collected multichannel seismic reflection profiles from the Ionian Basin to characterize the deep basin Messinian evaporites. These evaporites were deposited in deep and marginal Mediterranean sedimentary basins as a consequence of the "salinity crisis" between 5.97 and 5.33 Ma, a basin-wide oceanographic and ecological crisis whose origin remains poorly understood. The seismic markers of the Messinian evaporites in the deep Mediterranean basins can be divided in two end-members, one of which is the typical "trilogy" of gypsum and clastics (Lower Unit - LU), halite (Mobile Unit MU) and upper anhydrite and marl layers (Upper Unit - UU) traced in the Western Mediterranean Basins. The other end-member is a single MU unit subdivided in seven sub-units by clastic interlayers located in the Levant Basin. The causes of these different seismic expressions of the Messinian salinity crisis (MSC) appear to be related to a morphological separation between the two basins by the structural regional sill of the Sicily Channel. With the aid of velocity analyses and seismic imaging via prestack migration in time and depth domains, we define for the first time the seismic signature of the Messinian evaporites in the deep Ionian Basin, which differs from the known end-members. In addition, we identify different evaporitic depositional settings suggesting a laterally discontinuous deposition. With the information gathered we quantify the volume of evaporitic deposits in the deep Ionian Basin as $500,000 \mathrm{~km}^{3} \pm 10 \%$. This figure allows us to speculate that the total volume of salts in the Mediterranean basin is larger than commonly assumed. Different depositional units in the Ionian Basin suggest that during the MSC it was separated from the Western Mediterranean by physical thresholds, from the Po Plain/Northern Adriatic Basin, and the Levant Basin, likely reflecting different hydrological and climatic conditions. Finally, the evidence of erosional surfaces and V-shaped valleys at the top of the MSC unit, together with sharp evaporites pinch out on evaporite-free preMessinian structural highs, suggest an extreme Messinian Stage 3 base level draw
\end{abstract}

This is an open access article under the terms of the Creative Commons Attribution License, which permits use, distribution and reproduction in any medium, provided the original work is properly cited.

(C) 2019 The Authors. Basin Research published by International Association of Sedimentologists and European Association of Geoscientists and Engineers and John Wiley \& Sons Ltd. 
down in the Ionian Basin. Such evidence should be carefully evaluated in the light of Messinian and post-Messinian vertical crustal movements in the area. The results of this study demonstrates the importance of extracting from seismic data the Messinian paleotopography, the paleomorphology and the detailed stratal architecture in the in order to advance in the understanding of the deep basins Messinian depositional environments.

\section{K E Y W O R D S}

evaporites, Ionian Basin, Mediterranean, Messinian salinity crisis, salt giant

\section{$1 \mid$ MOTIVATION OF THE STUDY}

The understanding of the Messinian salinity crisis (MSC; e.g. Ryan 2009; Roveri, Flecker, et al., 2014) as a Mediterranean basin-wide event requires an improved knowledge of the stratigraphy in the deep basins and continental margins, where the vast majority of the evaporitic deposits lay below today's seafloor.

The seismic markers of the deposition of Messinian evaporites in the deep Mediterranean basins (sensu Lofi, 2011, 2018) are (Supplementary Figure S1):

- the Lower Unit (LU), generally poorly known due to the high absorption of seismic energy by the upper evaporitic layers, inferred to be composed of gypsum and clastics;

- the reflector-less Mobile Unit (MU), corresponding to salt filling the basins and onlapping the Late Miocene continental margins;

- the Upper Unit (UU), consisting of a package of parallel and continuous reflectors, interpreted as an alternation of anhydrite and marl layers;

- the Complex Unit (CU), corresponding to a chaotic, discontinuous and variably transparent unit thought to be made of deposits of material eroded from upper to lower Mediterranean continental slopes during lower sea level phases of the MSC.

In addition, the following main observed seismic surfaces are: the Margin Erosion Surface (MES), identified on the upper margins and interpreted as a subaerial erosion related to the absence of the Messinian layers; the Bottom Surface (BS), which marks the base of the evaporitic deposits in the deep basins; the Top Surface (TS), which separates the MSC deposits from the overlying Plio-Quaternary units; the Intermediate Erosion Surface (IES), corresponding to local intermediate erosional truncation developed during the last MSC.

Two depositional end-members are identified in the Mediterranean Basins (Supplementary Figure S1). In the Western Mediterranean, a laterally continuous succession of the three seismo-stratigraphic units LU-MU-UU, $\sim 2.5 \mathrm{~km}$

\section{Highlights}

- First description of a new type of deepwater Messinian salt giant in the Ionian Sea.

- First quantification of the Messinian salt volume in the Ionian Sea.

- New seismic evidence of erosional surfces and Lago Mare deposits in the deep Ionian Basin.

- Further evidence of sea level lowering during the Messinian Salinity Crisis.

- Evidence for a different, physically separated deepwater Messinian salt basins in the Mediterranean.

thick, can be correlated across thousands of kilometres in the Algero-Balearic and Provençal basins with a fairly constant distribution (e.g. Dal Cin et al., 2016).

Conversely, in the Levant Basin the MSC is primarily represented by a single, different type of MU, up to $2 \mathrm{~km}$ thick, composed of up to six alternations of a transparent and layered seismic units (Bertoni \& Cartwright, 2006; Gvirtzman, Reshef, Buch-Leviatan, \& Ben-Avraham, 2013; Netzeband, Hübscher, \& Gajewski, 2006). According to Feng, Yankelzon, Steinberg, and Reshef (2016), this transparent layers consists of halite, and the internal reflections are caused by intercalated clastics. At the top of MU there is an additional thin (a few tens of metres) uppermost unit interpreted as a clastic-rich anhydrite unit overlain by an even thinner "LagoMare" facies (Afiq Formation; Gvirtzman et al., 2017). The presence of UU and LU has never been demonstrated in the Levant Basin, although analogous seismic facies have been recognized in the Antalia and Cilicia Basins (Cipollari et al., 2013; Geletti, Del Ben, Mocnik, \& Camerlenghi, 2018; Madof \& Connell, 2018) and in the Florence Rise (Loncke, Sellier, \& Mascle, 2011).

The causes of the differences in the seismic expressions of the MSC between the Western Mediterranean and the Levant Basin are not understood. They appear to be related to a morphological separation between the Western and Eastern 
Mediterranean basins by the structural regional sill of the Pelagian Sea/Sicily Channel (e.g. Roveri, Lugli, Manzi, Gennari, \& Schreiber, 2014).

The Ionian Sea (Figure 1a) is the deepest sedimentary basin in the Mediterranean, located in an intermediate position between the Western Mediterranean and the Levant Basin, right to the east of the Pelagian Sea/Sicily Channel regional sill. Shallow penetrating Deep Sea Drilling Project (DSDP) and Ocean Drilling Program (ODP) wells demonstrate the existence of evaporitic deposits below a Pliocene
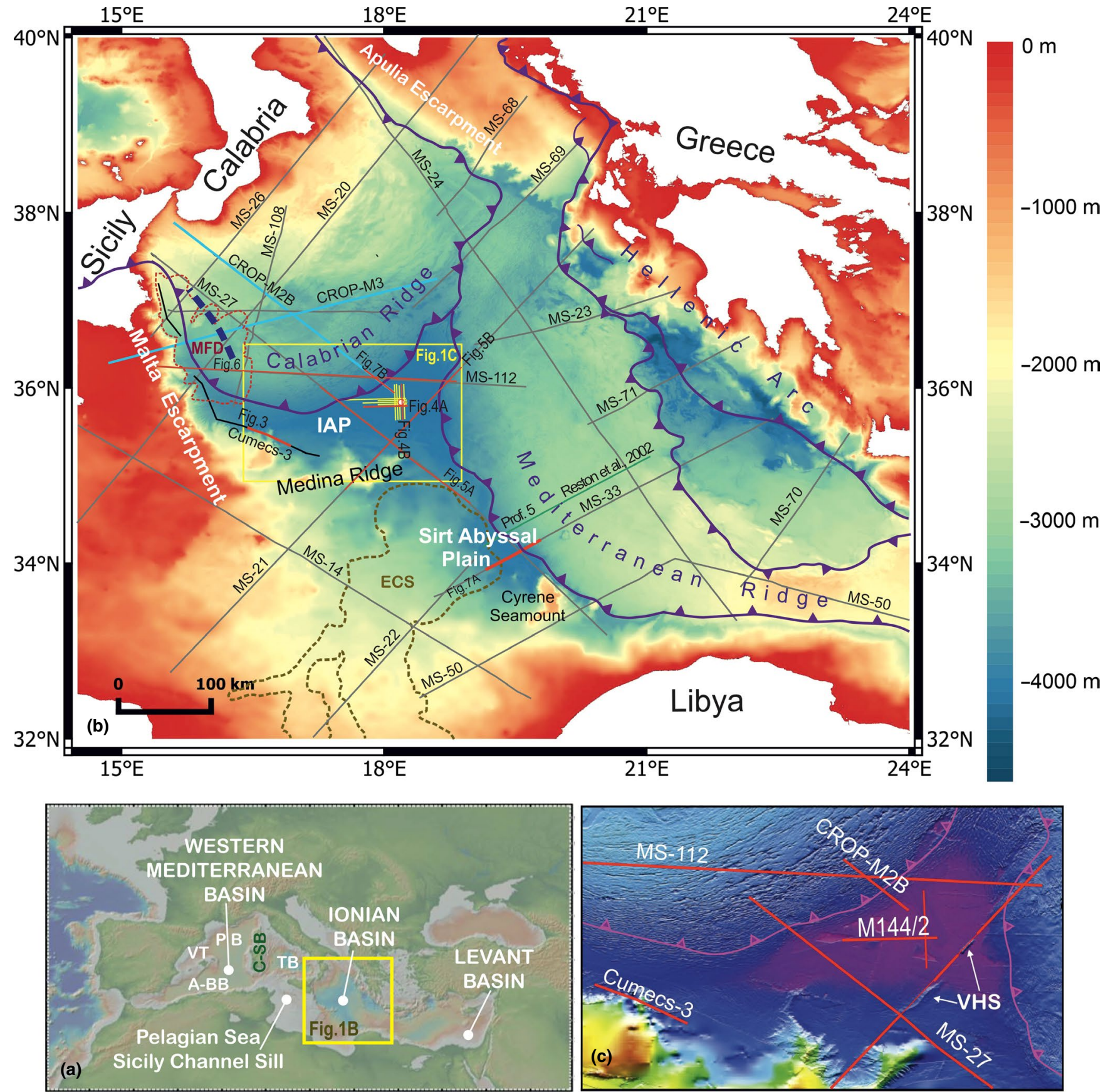

F I G U RE 1 (a) Study area, in the central Mediterranean Sea (GeoMapApp) with location of figures. A-BB, Algero-Balearic Basin; C-SB, Corsica-Sardinia Block; PB, Provençal Basin; TB, Tyrrhenian Basin; VT, Valencia Trough. (b) Bathymetry, main structural elements (Arsenikos et al., 2013; Del Ben et al., 2008, 2015; Finetti \& Del Ben, 1986; Kokinou et al., 2005; Mocnik et al., 2018; Reston, Fruehn, et al., 2002) and seismic line location. Red lines on seismic profiles indicate the portion of the profile illustrated in the figure. IAP is the Ionian Abyssal Plain. The thin brown dashed lines highlight the Zanclean Megaflood Deposits (MFD) after Micallef et al. (2018), at the foot of the Malta Escarpment, and the Eosahabi Channel System (ECS), in the Sirt Gulf after Bowman (2012); Thick blue-dashed line: surface expression of the STEP Fault (various sources). (c) Detail of the Ionian Abyssal Plain with location of profiles crossing the area and of the Victor Hensen Seahills structures, discussed in the text 
to Quaternary sedimentary fill. On the contrary, little is known about the deeper stratigraphy, investigated exclusively through geophysical methods, mainly reflection seismics. It is known that a Messinian salt sequence is present below the Ionian and Sirt abyssal plains. However, likely due to the intense post-Messinian deformation affecting the Ionian crust as a response to the Calabrian and Hellenic subduction systems (Figure 1b), the structure of the MSC sequence in the Ionian Basin is poorly constrained.

Here, we report on the seismic signal analysis performed on vintage and recently collected multichannel seismic reflection profiles bearing variable vertical and horizontal resolution from the Ionian Basin. Given the intense tectonic deformation, the challenge in this area is the identification of an undisturbed deep sea evaporitic sequence where the data quality allows a reliable reconstruction of the MSC stratigraphy. With the aid of extensive velocity analyses, pre-stack migration in time and depth domains, and seismic imaging, we have been able to define for the first time the seismic signature of the Messinian evaporites in the deep Ionian Basin, which differs from the known Western Mediterranean and Levant Basin end-members. In addition, the rough preMessinian topography in the deep Ionian Basin allows to identify different evaporitic depositional settings suggesting a laterally discontinuous deposition of evaporites. With the information gathered, we quantify the volume of evaporitic deposits in the region.

\section{2 | GEOLOGICAL SETTING}

During the Mesozoic, the Mediterranean region was part of the east-west-oriented Tethys Ocean and its passive continental margins. The Mediterranean geodynamic evolution has been strongly affected by the convergence of the African and Eurasian plates (Ben-Avraham et al., 2006; Carminati \& Doglioni, 2005; Maesano, Tiberti, \& Basili, 2017), which produced the closure of the previous oceanic domain and a complex system of contractional structures along the basin margins (e.g. Camerlenghi \& Pini, 2009, their Figures 3-5).

The Eastern Mediterranean is widely considered a relic of the southern margin of the Tethys Ocean (Biju-Duval, Letouzey, \& Montadert, 1978; Carminati \& Doglioni, 2005; Dannowski et al., 2019; Dellong et al., 2018), not yet completely involved in the subduction zones initiated in the Cenozoic with the Alpine-Himalayan orogenesis. The Mediterranean and Calabrian ridges represent two accretionary complexes facing an incipient continental collision (Costa et al., 2004; Finetti \& Morelli, 1973; Polonia, Camerlenghi, Davey, \& Storti, 2002; Polonia et al., 2017; Reston, Fruehn, von Huene, \& IMERSE Working Group, 2002; Reston, von Huene, Dickmann, Klaeschen, \& Kopp, 2002; Valenti, 2011).
In contrast, the Western Mediterranean basin is a younger though complex system of back-arc basins related to the north-western Tethyan subduction, initiated by continental rifting in the Oligocene with the opening of the Valencia Trough (e.g. Granado et al., 2016). It continued with oceanic spreading in the Algero-Balearic Basin and opening of the Provençal Basin by counterclockwise rotation of the Corsica-Sardinia block. This was followed by the Late Miocene to Recent opening of the Tyrrhenian Basin (BijuDuval et al., 1978; Carminati, Lustrino, \& Doglioni, 2012; Doglioni, Gueguen, Sàbat, \& Fernández, 1997; Finetti \& Del Ben, 1986; Krijgsman, 2002; Sàbat et al., 1997).

The Ionian Basin is part of the Eastern Mediterranean, bordered to the west by the Malta Escarpment and eastern Sicilian Margin, to the north by the Calabrian Ridge, to the east by the Mediterranean Ridge and to the south by Africa margin in the Sirt Gulf. Contoured by the $4,000 \mathrm{~m}$ isobath are the nearly $5,000 \mathrm{~km}^{2}$ of flat Ionian Abyssal Plain (Hieke, Hirschleber, \& Dehghani, 2003) bordered to the south by the east-west-trending Medina Ridge (Figure 1).

Although the nature of the crust underlying the Ionian Basin is still debated, most researchers agree on the oceanic nature as a remnant of the Mesozoic Tethys Ocean crust with its transition into continental crust to the western and southern margins (Carminati \& Doglioni, 2005; Gallais, Graindorge, Gutscher, \& Klaeschen, 2013; Gutscher et al., 2017; Polonia et al., 2017; Speranza, Minelli, Pignatelli, \& Chiappini, 2012; Valenti, 2011). In particular, the Triassic or pre-Triassic age has been postulated by Stampfli (2005), Speranza et al. (2012) and Maesano et al. (2017), implying that the Ionian Basin comprises the oldest oceanic crust on Earth.

The Ionian lithosphere is undergoing NW-oriented subduction below the Calabrian Ridge, demonstrated by hypocentres below the Tyrrhenian Sea as deep as $600 \mathrm{~km}$ (e.g. Vannucci et al., 2004) and driven by NW-directed African and Eurasian relative plate convergence (Del Ben, Geletti, \& Mocnik, 2010; Mantovani, Viti, Babbucci, \& Albarello, 2007). The transition to the Sicilian continental lithosphere to the west is thought to be located at the foot of the Malta Escarpment. A sub-vertical lithospheric tear fault or STEP (sensu Govers \& Wortel, 2005) has been proposed by many authors as a lithosphericscale structure that is nearly parallel to the Malta Escarpment, above which a mainly right trans-tensional system cuts into the Calabrian Ridge (Del Ben, Barnaba, \& Taboga, 2008; Dellong et al., 2018; Gallais et al., 2013; Gutscher et al., 2017; Maesano et al., 2017). Polonia et al. (2016, 2017) interpret a main STEP separating the westernmost sector of the Ionian oceanic lithosphere from the eastern subducting sector. The same Ionian lithosphere is being subducted to the NE below the Hellenic Arc in response to the Aegean back arc opening to the SW (e.g. Brun et al., 2016).

The deformation of the post-Messinian sequence of the Calabrian Ridge (Mocnik, Del Ben, Camerlenghi, 
Geletti, \& Saule, 2018; Polonia et al., 2016) and of the Mediterranean Ridge (Reston, Fruehn, et al., 2002; Reston, von Huene, et al., 2002) accretionary complexes influence the morphology of the northern and western edges of the Ionian Abyssal Plain. Slope gradients between $0.5^{\circ}$ and $2^{\circ}$ are generated by gentle anticlinal folds of the outer deformation fronts bordering the abyssal plain. Conversely, along the Medina Ridge and Malta Escarpment, the seafloor rises abruptly above the abyssal plain as high and steep slopes (Ben-Avraham et al., 2006; Gutscher et al., 2017; Hieke et al., 2003) (Figure 1).

In the southern part of the Ionian Abyssal Plain, some abyssal hills and seamounts are present, elongated in a NESW direction (Figure 1c). The greatest of them is the Victor Hensen Seahill (VHS), with an elevation of about $320 \mathrm{~m}$ above the surrounding seafloor, which represents the NE structural continuity of the Medina Ridge (Hieke \& Dehghani, 1999; Hieke et al., 2003).

\section{3 | MESSINIAN SALINITY CRISIS IN THE MEDITERRANEAN}

The Messinian salinity crisis (MSC) is an ecological crisis induced by a combination of geodynamic and climatic drivers, among which was the reduction in water exchange between the Mediterranean and the Atlantic. These drivers led to excess evaporation in the Late Miocene and widespread deposition of evaporitic minerals in deep and marginal sedimentary basins. Whether or not the event was accompanied by a major sea level drawdown, as the theory of the desiccation of the Mediterranean implies (Hsü et al., 1978), is a matter of long-lasting scientific debate (see the contrasting hypotheses in Bache et al., 2012; Blanc, 2006; Roveri, Flecker, et al., 2014; Roveri, Lugli, et al., 2014; Ryan, 2008, 2009).

The end of the MSC is interpreted in various and contrasting ways. According to the desiccation theory, the return to normal open marine conditions in the Mediterranean, which characterizes the Zanclean stage of the Pliocene, was driven by a mega flood (MF) of the Western Mediterranean, through the Gibraltar area, and of the Eastern Mediterranean through the Pelagian Sea/Sicily Channel sill (Estrada et al., 2011; Garcia-Castellanos \& Villaseñor, 2011; Garcia-Castellanos et al., 2009). The evidence for the MF deposit has been reported in multichannel seismic reflection profiles in the Western Ionian Sea by Micallef et al. (2018). Elsewhere in the Eastern Mediterranean the sedimentary record of the termination of the MSC is characterized in the seismic reflection record by fan-shaped, fluvio-deltaic formations resting on the Messinian salt unit, well imaged in the Sirt Basin (Lago Mare of Bowman, 2012) and in the Levant Basin (Gvirtzman et al., 2017; Madof, Bertoni, \& Lofi, 2019; Wescott \& Boucher,
2000). Where detectable, a thin seismic unit (Gvirzman et al., 2017) may represent the seismo-stratigraphic expression of the Lago Mare biofacies association, described in samples from outcrop and DSDP wells as the evidence of a brackish water terminal phase of the MSC with biostratigraphic indicators of a Paratethys (Eastern European) origin. In the Alboran Sea (Westernmost Mediterranean), Do Couto et al. (2014) interpret the Lago Mare deposits as an event that followed the marine reflooding ending the MSC during the latest Messinian on the basis of sedimentological and stratigraphic observations.

\section{4 | DATA AND METHODS}

\section{1 | Vintage, deep penetration seismic dataset}

Vintage multichannel seismic reflection data used in this work were acquired in the framework of two different research projects: MS (Mediterranean Sea) (Finetti \& Morelli, 1973) and CROP (CROsta Profonda) (Finetti, 2005; Scrocca et al., 2003) (Figure 1).

The MS project was a pioneering geophysical investigation that covered extensive areas of the Mediterranean Sea, performed by the Osservatorio Geofisico Sperimentale (OGS) of Trieste (renamed Istituto Nazionale di Oceanografia e di Geofisica Sperimentale - OGS - in December 1999) from 1969 to 1982 . The MS dataset is composed of over $34,000 \mathrm{~km}$ of seismic lines, located in the Mediterranean Sea, in order to provide crustal imaging in the shallow and deep basin areas.

Seismic profiles of the CROP regional project, sponsored by CNR, ENEL and ENI, were acquired by OGS from 1988 to 1995 to investigate the deep crustal structures. The large source-receivers offset in these profiles have permitted an accurate field velocity analysis for a pre-stack $2 \mathrm{D}$ time/depth migration.

The acquisition parameters of CROP and MS profiles are provided in Supplementary Material Table S1.

\section{2 | Modern, high-resolution multi-channel seismic data set}

\subsection{1 | CUMECS-3 seismic survey}

A survey of R/V OGS Explora was run in 2015 with the purpose of identifying mass transport deposits and Messinian incisions along the base of the Malta escarpment. High-resolution multi-channel seismic reflection profiles were collected using a source array made of 1 GI-gun and 1 Mini GI-gun, with a total volume of $4.4 \mathrm{~L}$ fired every 15.6 or 18.7 m. A 300-m-long Geometrics GeoEel digital streamer recorded 96 traces with $3.125 \mathrm{~m}$ spacing, resulting in 9.6-8fold coverage. The sampling rate was $0.5 \mathrm{~ms}$. 


\subsection{2 | M144/2 seismic survey}

In 2018, the University of Hamburg conducted a multi-channel reflection seismic survey in the central Ionian Sea centred at DSDP42 Site 37 with RV Meteor expedition M142/2 (Hübscher et al, 2018). The seismic signal was generated by a sparker, which consisted of three pairs of electrodes. Every $9 \mathrm{~s}$ these electrodes created an electric arc, which in turn evaporated the waters. The collapse of this underwater water steam created the seismic signal. A 6 kJoule power unit provided the necessary power. A digital 144-channel streamer with an active length of $600 \mathrm{~m}$ was used for the survey. The re-processing steps and the methods of seismic interpretation are described in the Supplementary material.

\section{5 | RESULTS}

\section{1 | Seismic stratigraphy and calibration}

The seismic sections analysed in this study highlight the presence of a main MSC sequence in the Ionian Abyssal Plain overlain by the Plio-Quaternary (PQ) unit and underlain by the pre-MSC units (Figure 2).

\subsection{1 | Plio-Quaternary (PQ) seismic facies unit}

The PQ seismic facies unit (Figure 2a-d) is bounded at its top by the sea bottom reflector, found at an average depth of about 4,000 m (5.3 ms twt) in the Ionian Abyssal Plain. The unit displays variable, generally low-amplitude and high-frequency reflectors with good lateral continuity. The geometry of reflectors is sub-planar, gently folded or sub-parallel, including large sediment waves in its upper part along the western margin of the basin (foot of the Malta Escarpment and Sicily margin, Figures $2 \mathrm{~b}$ and 3 ). The lower boundary is a complex surface marked by a dramatic increase in reflector amplitude along the top of the underlying MSC sequence. Below the Ionian Abyssal Plain, this interval is subdivided into three sub-units (PQa, PQb and PQc) characterized by different deformation intensities and reflector strength (Figure 2a).

The upper sub-unit PQa is made of parallel and laterally continuous reflectors with moderate amplitude. In its lower part, the high-resolution data outline a rather thick (about $50 \mathrm{~ms} \mathrm{twt}$ ) layer of low-amplitude reflectors that are almost transparent in places. The lower boundary of this low-amplitude layer marks the transition to the underlying sub-unit PQb, composed of sub-parallel and laterally continuous high-amplitude reflectors. Reflector terminations define a marked basal angular unconformity close to the deformation front of the Calabrian Ridge (Figure 2c). The lowest PQc subunit is marked by significantly lower reflection strength than above, with lateral reflectivity changes, particularly evident in the high-resolution data (Figure 2a). The transition from the base of unit PQc to the underlying MSC unit is characterized by a thin $(20-30 \mathrm{~m})$ irregular layer with poor lateral continuity of reflectors with a higher amplitude than the overlying PQc drape (Figure 4c,d). When approaching the Calabrian Ridge deformation front, sub-unit PQc shows coherent deformation with the underlying MSC sequence (Figure 2c).

At a basin scale, the PQ unit bears a basin-fill geometry with a depocentre located in the Ionian Abyssal Plain. Its shape is that of a wedge onlapping and thinning towards the Calabrian and Mediterranean ridges and the Medina Ridge and thickening towards the outer deformation front of the Calabrian Ridge (Figure $4 b$ ). The thickness changes in the PQ unit are produced primarily in sub-units "a" and "b", while sub-unit "c" bears a rather uniform thickness, though conformably folded with the underlying MSC unit and separated by the overlying $\mathrm{PQb}$ unit by a marked unconformity(Figure 4).

\subsection{2 | Messinian salinity crisis (MSC) sequence}

The MSC sequence (Figure 2e-h) is bounded at its top by a very high-amplitude normal-polarity continuous reflector in low-resolution data (Figure 2g,h). In high-resolution data (Figure 2e,f) the upper boundary of the MSC sequence maintains its character of high amplitude and normal polarity, while the lateral continuity appears to be much less pronounced. The boundary is not planar and comprises lateral terminations in places (Figures 3 and 4). The lower boundary is a laterally continuous, high-amplitude reflector with reverse phase relative to the seafloor (negative polarity) (Figures 2e-n and 5-7).

The seismic stratigraphy of the MSC sequence from the low-resolution data includes two main seismic facies units, from top to bottom (Figure $2 \mathrm{~g}-\mathrm{i}$ ):

- A high-amplitude unit with poor lateral continuity, at times chaotic internal configuration, with evidence of irregular folding (UU).

F I G U RE 2 Examples of the seismic units discussed in the text located in the Ionian Abyssal Plain. (a) undeformed PQ sub-units. (b) PlioQuaternary contouritic facies (sediment waves) overlying the MSC units at the foot of the Malta Escarpment. (c,d) progressive deformation in PQ at the south-eastern front of the Calabrian Ridge. (e) MSC units in marginal position, at the foot of the Malta Escarpment. (f) MSC Units in the central Ionian Abyssal Plain. (g,h) MSC units deformation at the front of the Calabrian Ridge and between the opposite fronts of the Calabrian and the Mediterranean ridges. (i) MU filling structural in pre-MSC units. (1) high angle faults and pop-up structures in pre-MSC units. (m) high-angle normal faults in pre-MSC units. The uninterpreted seismic profiles are available as Supporting information. (n) Location map 


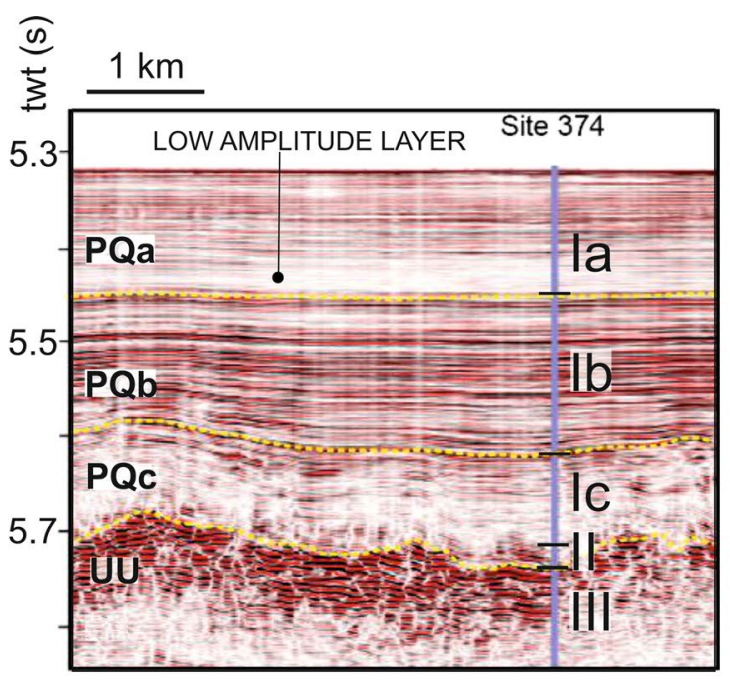

(a) undeformed $P-Q$ unit.

High resolution data

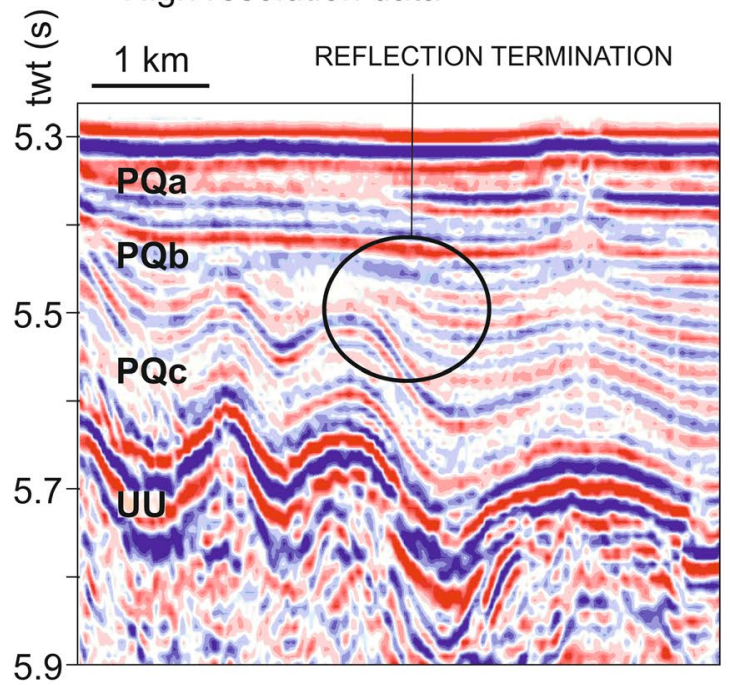

(c) moderately deformed $\mathrm{P}-\mathrm{Q}$ unit. Low resolution data

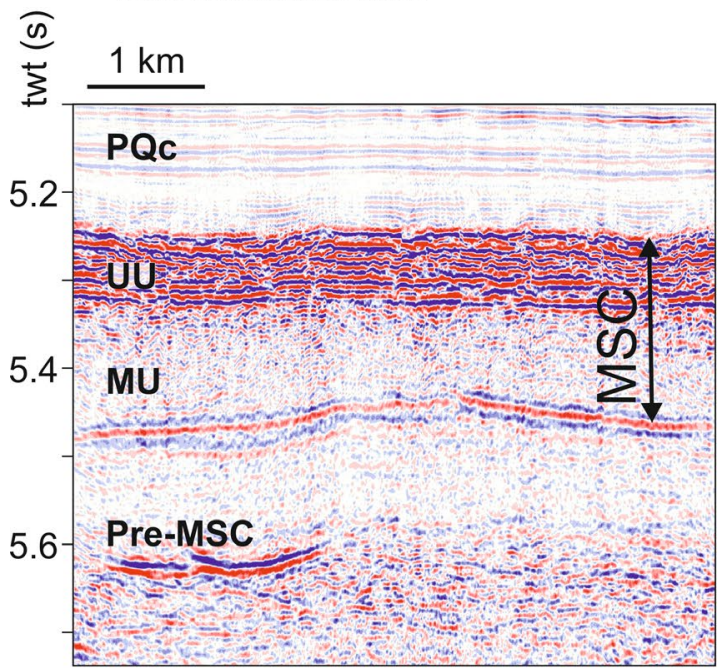

(e) undeformed marginal MSC unit. High resolution data

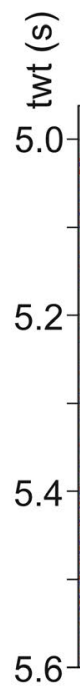

(b) contouritic $P-Q$ unit.

High resolution data

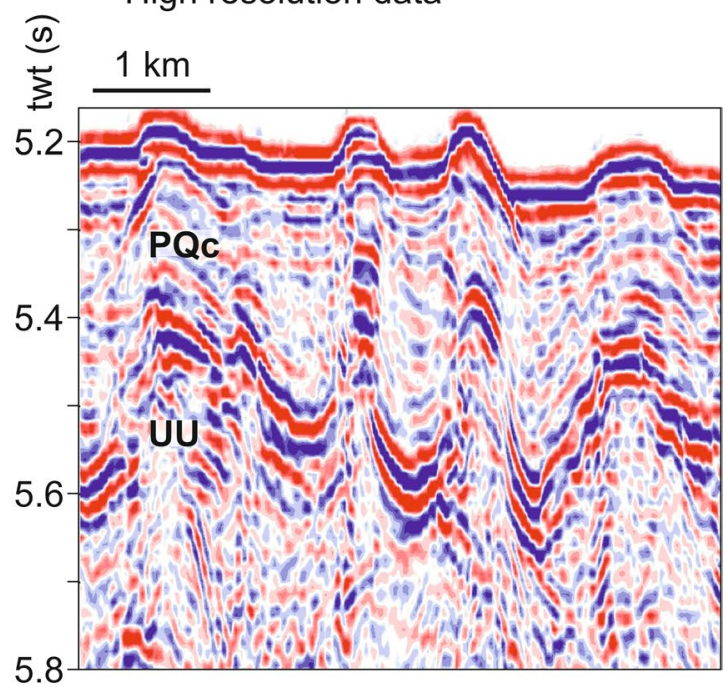

(d) intensively deformed $P-Q$ unit. Low resolution data

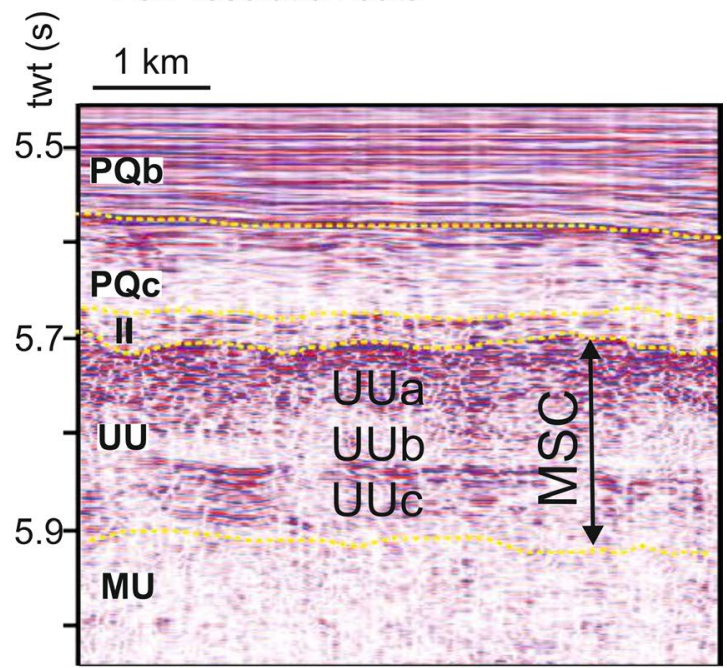

(f) undeformed basinal Top MSC unit. High resolution data 


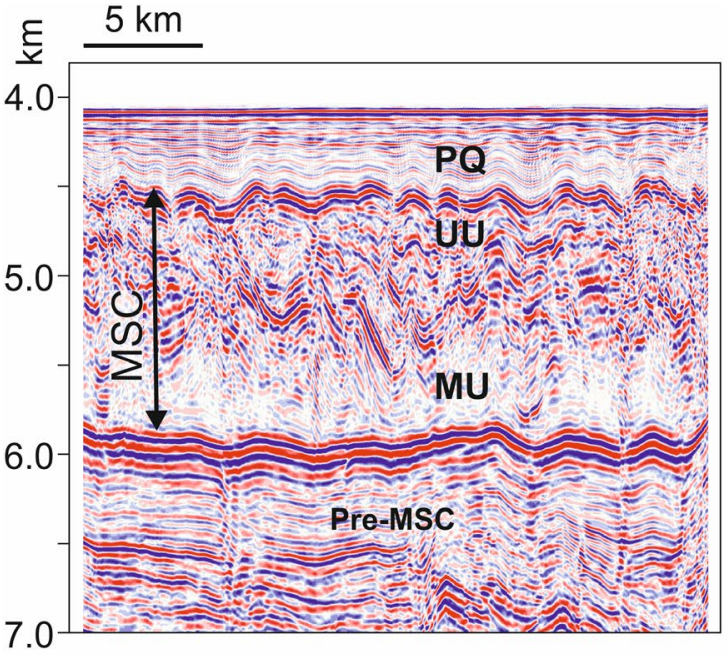

(g) moderately deformed MSC unit. Low resolution data

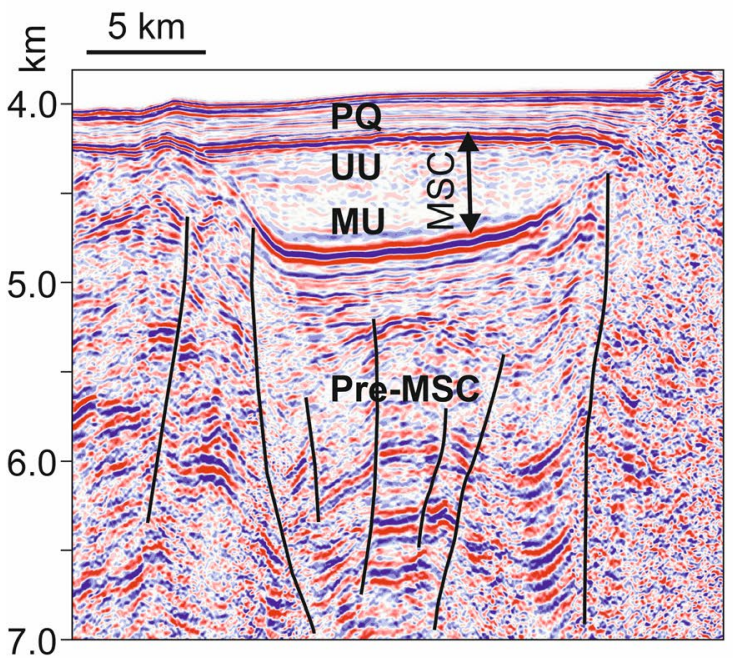

(i) structures in pre-MSC unit. Low resolution data

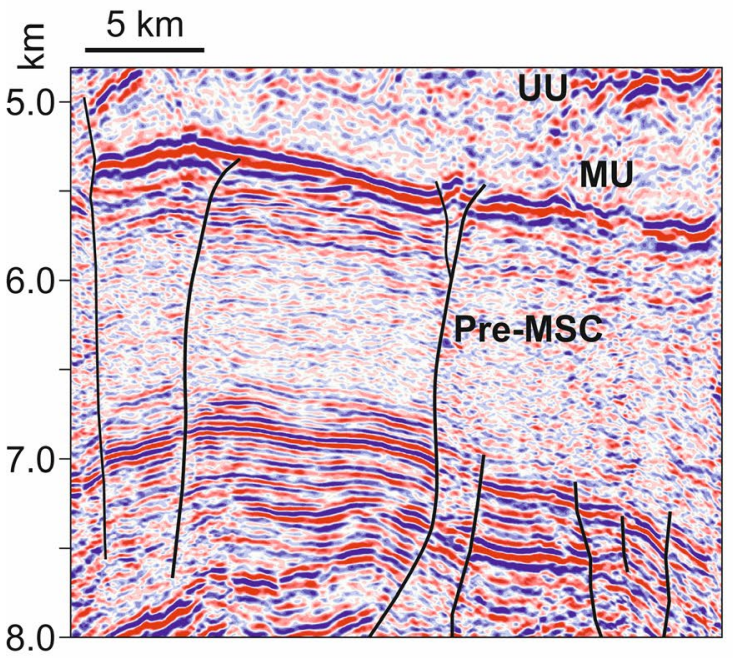

(m) pre-MSC unit. Low resolution data

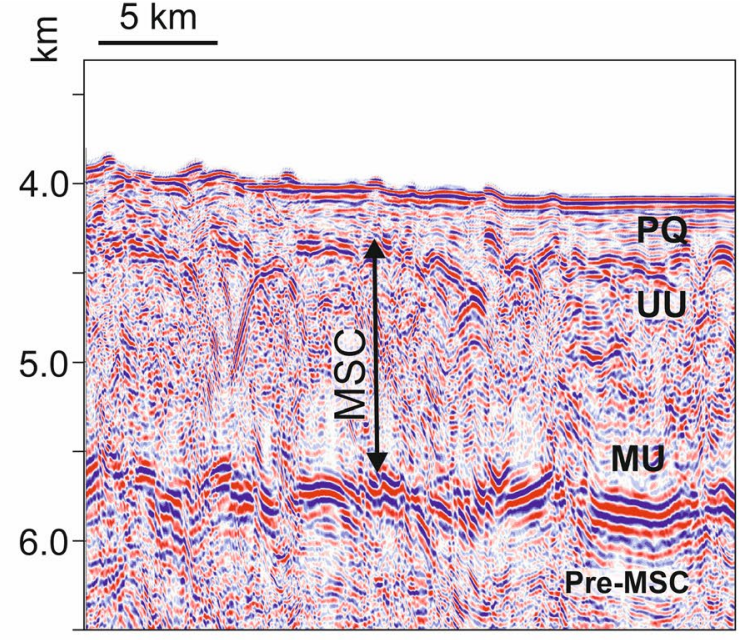

(h) intensively deformed MSC unit. Low resolution data

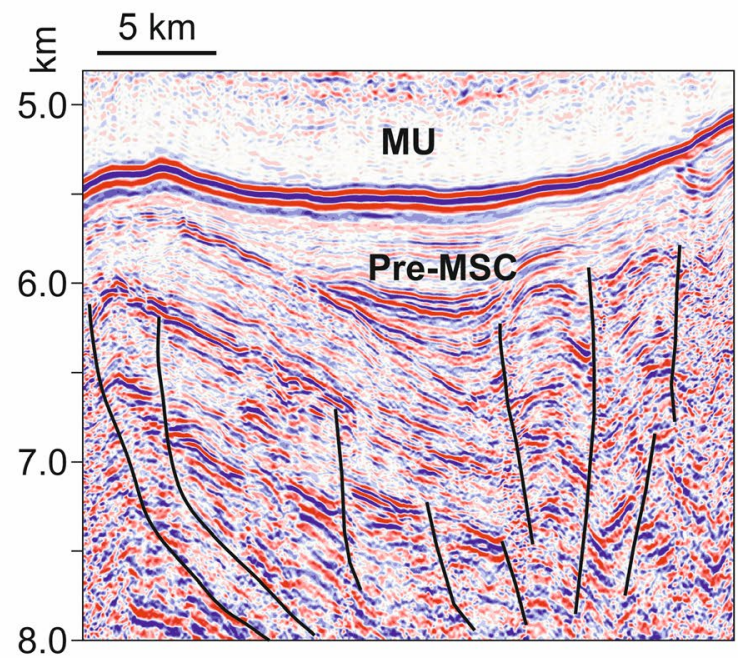

(I) pre-MSC unit. Low resolution data

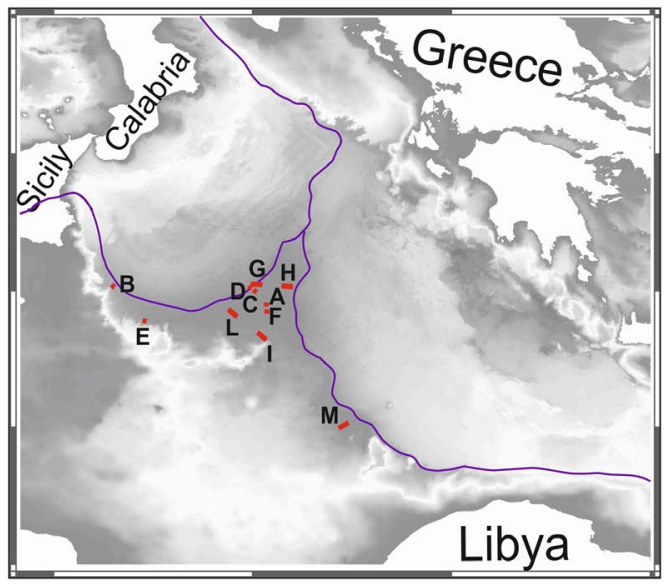

(n) position map of the seismic lines in the figures $3 a$ and $3 b$ 


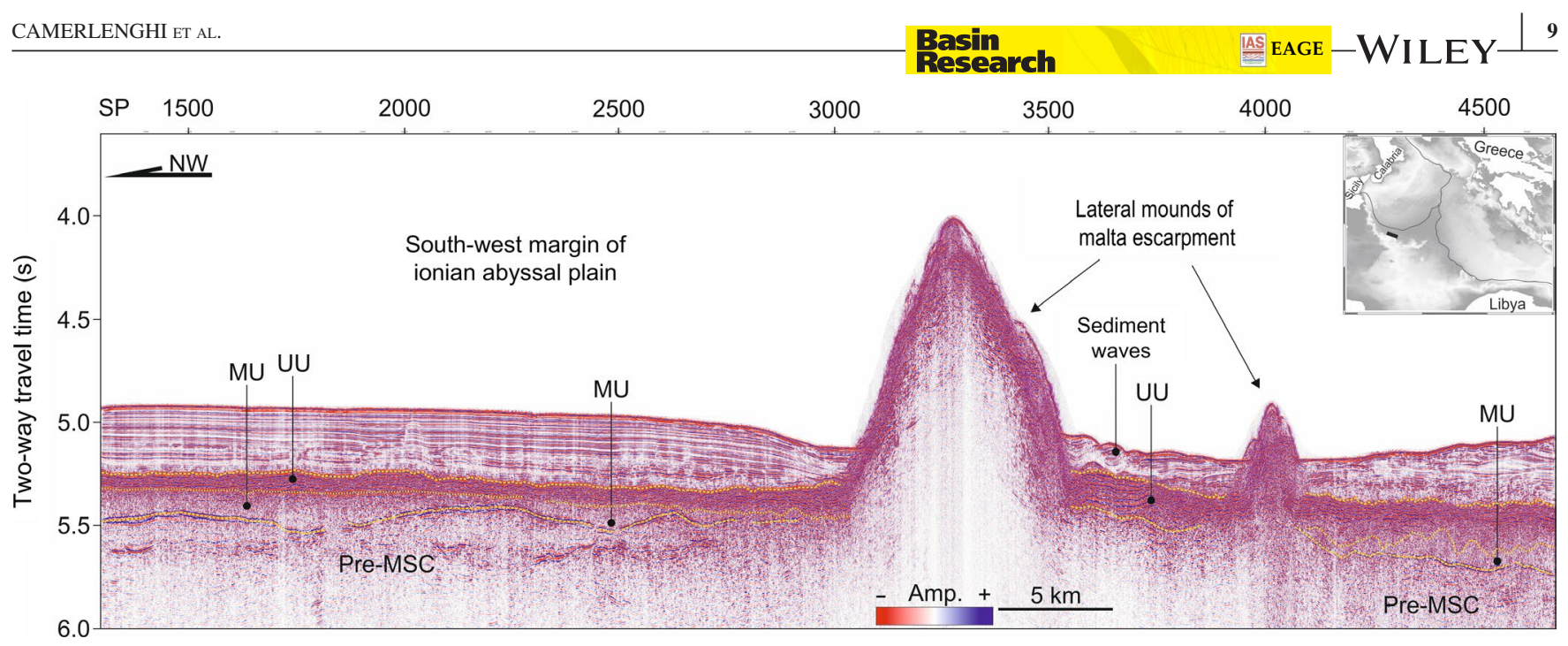

F I G U R E 3 Time-migrated, high-resolution seismic profile CUMECS-3 illustrating PQ and MSC units onlap on structural highs of the Malta Escarpment/Medina Ridge system. Note the sediment wave and contouritic facies of PQ and the sharp base of MU reflector, that seem to seal the pre-existing morphology, probably produced by mass transport deposits. Unlike the Ionian Abyssal Plain, the MU/UU boundary is a sharp transition. The thickness and facies of the MSC units differ on the two sides of the Malta Escarpment structures. See text for discussion. The uninterpreted seismic profiles are available as Supporting information

- A seismically transparent unit with a marked discordance between the lower, nearly flat boundary and the upper folded boundary (MU). The upper boundary is not a clear reflector. The transition appears as a gradual one, characterized by an upward decrease in transparency in the seismic facies. The gradual transition is particularly evident in the seismic attributes of reflection strength and relative acoustic impedance (Figure 8a).

The MSC unit displays a clear basin-fill geometry with a rather uniform thickness below the Ionian Abyssal Plain. Below the Ionian Abyssal Plain, the upper part of UU displays a clear synform geometry with reflection terminations against the lower boundary of PQ (Figures 5a and 8a). Its lateral extent is controlled southwards by the Medina Ridge and by other buried structures against which the unit onlaps abruptly (Figure 5). In the Sirt Basin, southeast of the Medina Ridge, the distribution of the MSC unit is more complex, with lateral discontinuities defining smaller sub-basins controlled by a preexisting topography due to tectonic deformation (Figure 5a).

The seismic stratigraphy of the MSC sequence from highresolution data differs from the low-resolution data (Figure 2e,f):

The high-amplitude upper unit UU is marked by a clearcut lower boundary (Figures 2e and 3 between SP 1,500 and 3,000 ) at the Western Ionian basin margin (foot of the Malta Escarpment). In the deepest part of the basin (Figures $2 \mathrm{f}$ and 3 between SP 3,500 and 4,500, and Figure 4), the lower boundary to UU is transitional. In the basin centre (Figures $2 \mathrm{f}$ and 4a,b) UU appears as composed by an upper high reflectivity interval with a thickness of about $150 \mathrm{~m}$ (UUa) changing gradually downwards to a transparent interval about $160 \mathrm{~m}$ thick (UUb) underlain by a high-reflectivity and laterally continuous reflector package that in most of the cases acts as acoustic basement (UUc).

The upper boundary is always highly irregular, with undulations and apparent incisions (Figures 3 and 4). Internally, reflector continuity is weak.

\subsection{3 | Pre-Messinian salinity crisis (pre- MSC) seismic facies units}

The pre-MSC units is well characterised by laterally continuous, high-amplitude, generally sub-parallel reflectors. The latter are mostly gently dipping (with inclination of about $5^{\circ}$ calculated in the depth sections), and offset by sub-vertical faults, flower and pop-up structures (Figures 2i-m and 5). In line MS 27 North of the Medina Ridge (Figure 5a, left part), below the Ionian Abyssal Plain, are two sedimentary wedges with upper boundaries conformable to the base of the MSC unit and lower boundaries markedly unconformable over a highly deformed reflective unit. The sedimentary wedges represent growth strata (gs) confined between faults up to the shallowest pre-MSC reflector. Fault activity seems to also affect the base of the MSC sequence locally (Figure 5).

South of the Medina Ridge (Figure 5a, right part), the pre-MSC seismic response is mainly reflectorless, with no evidence of the sedimentary wedges and tectonic structures visible to the north. In addition, the boundary between the MSC and pre-MSC units is highly irregular, probably in response of a closely spaced pattern of fractures and faults not imaged in the seismic data. A prominent structural high, similar to the Medina Ridge and VHS-2 structures, is present farther to the SE (Figure 5a, approx. SP 100), which separates laterally two MSC units and generating a bathymetric 


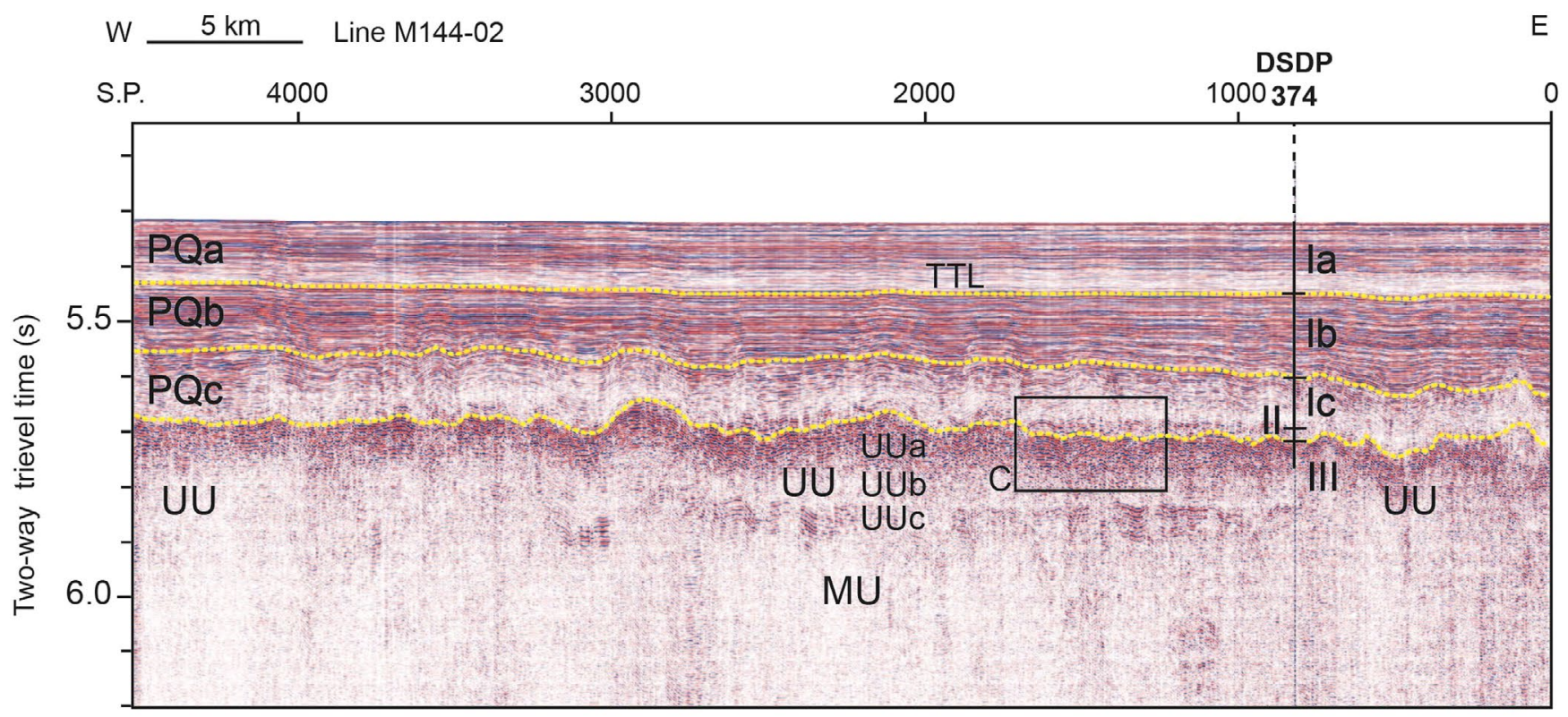

(a)

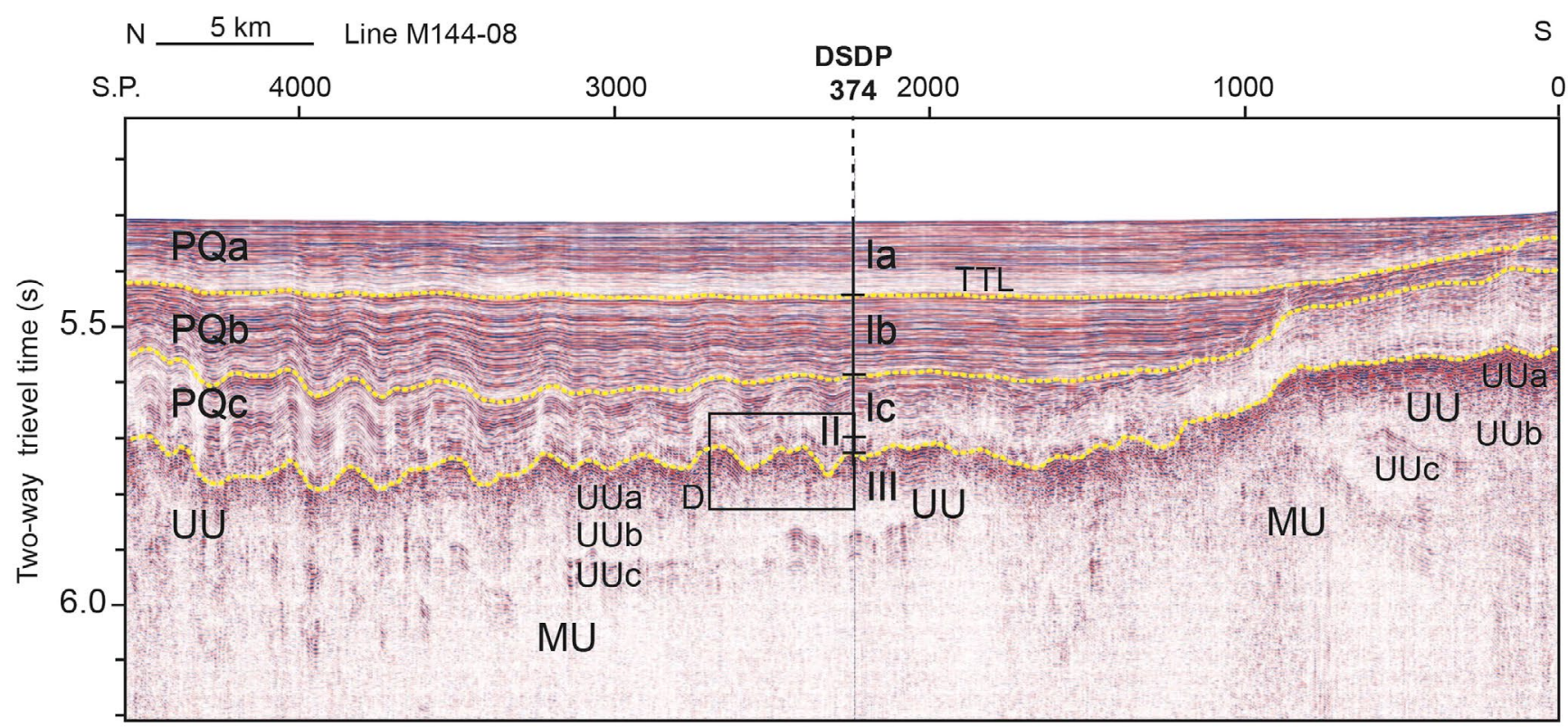

(b)

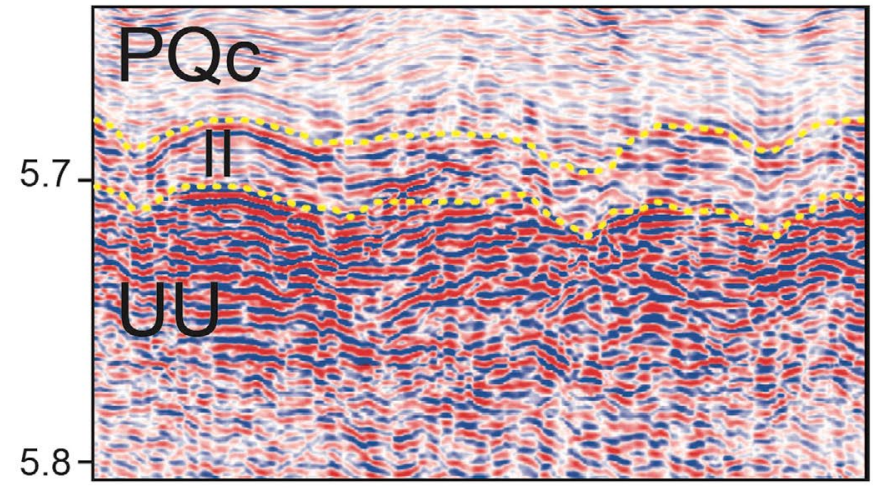

(c)

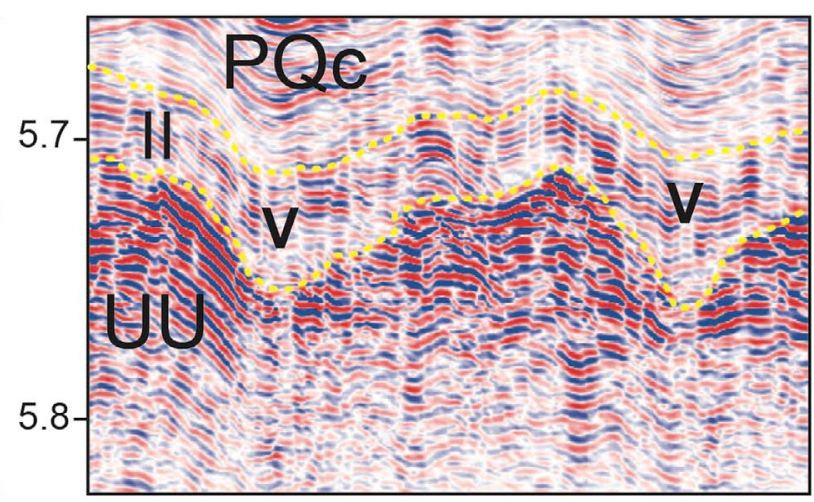

(d) 
F I G U RE 4 (a,b) High-resolution imaging of the Plio-Quaternary and Messinian Upper Unit (UU) stratigraphy in the Ionian Abyssal Plain tied with DSDP Site 374. The seismic stratigraphy of the Plio-Quaternary (PQ) sequence is composed of three units (PQ a,b,c) correlating with Lithostratigraphic Units I a,b,c drilled at Site 374. The Messinian evaporites are imaged only in their upper part (Upper Unit UU). UU appears as an alternation of highly reflective and acoustically transparent layers (UU a,b,c). Lithostratigraphic Unit II is made of lower Pliocene dolomitic marls recovered in $8.5 \mathrm{~m}$ of core in DSDP Site 374. Its occurrence in the seismics is defined by a higher reflectivity layer above the top of UU, consistently found in the high-resolution seismic data (c,d). The MSC-PQ boundary is a highly irregular surface, describing apparent V-shaped incisions in UU (indicated with the symbol V). See text for details. The uninterpreted seismic profiles are available as Supporting information

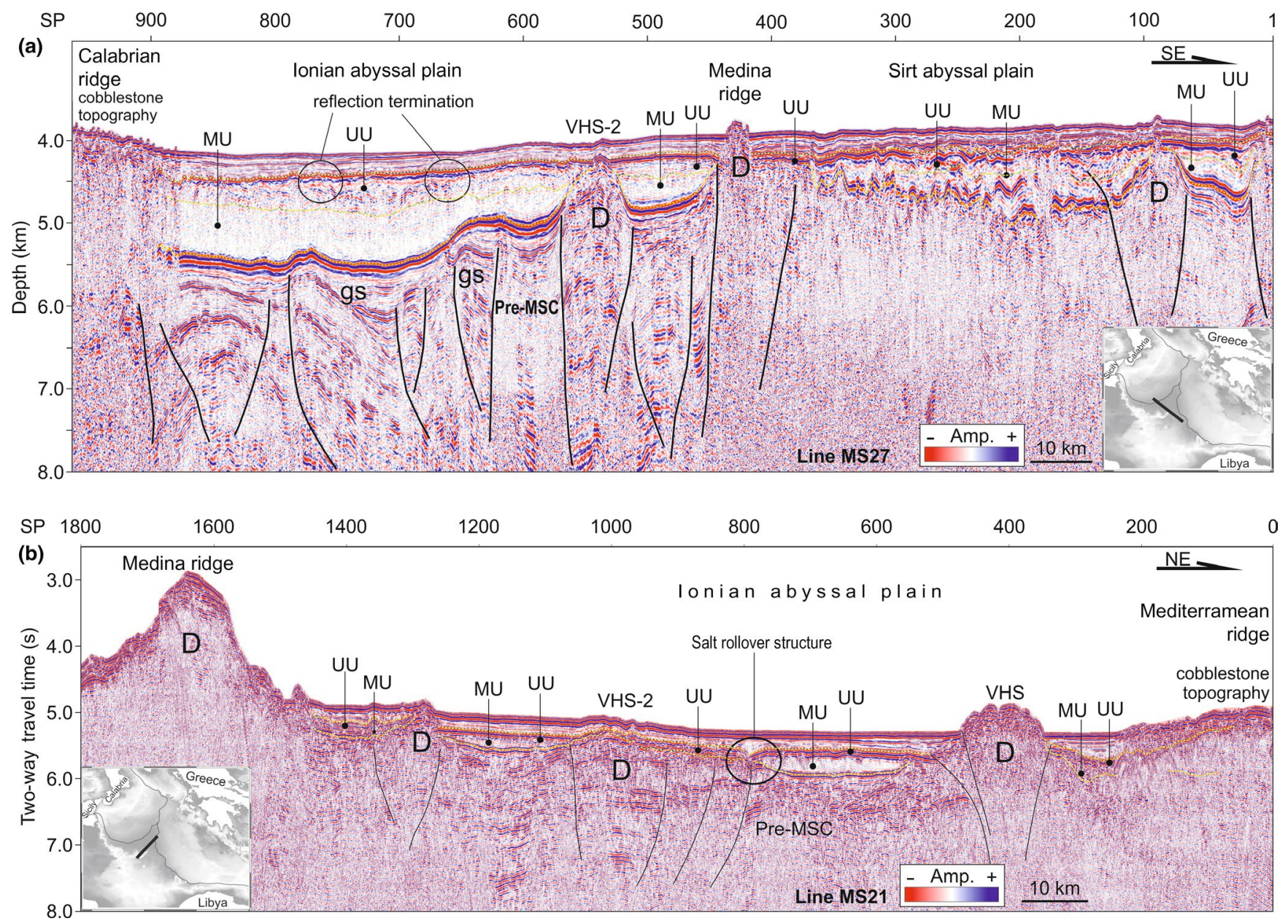

F I G URE 5 (a) Part of the depth-migrated seismic profile MS-27 crossing the front of the Calabrian Ridge and the Victor Hensen Seahill-2 (VHS-2) and the Medina Ridge (see Figure 1c for location). Note how the MSC units are thicker in the Ionian Abyssal Plain, where the upper part of the UU defines a synform with possible truncations. Both UU and MU onlap the structural highs of the Medina Ridge and VHS-2. In the Sirt Abyssal Plain the distinction between the MU and UU is very weak, the overall thickness of the MSC units is lower and the degree of deformation is higher. With "gs" we outline growth strata. With "D" we outline doming in the strata. The uninterpreted seismic profiles are available as Supporting information. (b) Part of time-migrated profile MS-21 crossing the Medina Ridge and the VHS structures in the Ionian Abyssal Plain. Note the presence of four distinct Messinian evaporitic basins in which the evidence for UU increases with water depth. MU clearly onlaps the sides of the structural highs (VHS, VHS-2 and Medina Ridge), while UU drapes VHS-2. The uninterpreted seismic profiles are available as Supporting information

relieve. SE of this structure the pre-MSC units is again well stratified.

Below the Sirt Abyssal Plain (Figure 7a) the unit immediately below the MSC is highly reflective and underlain by a thick low reflectivity unit (about $1 \mathrm{~km}$ ), resting over a highly reflective unit encompassing lateral onlaps and thickness changes.
Doming (D) into the pre-Messinian units has been identified near the south-eastern edge of the abyssal plain (Figure 5), showing a transparent to chaotic seismic facies and generally related to flower structures. They separate basins filled by sub-horizontal MSC reflectors, which display onlap termination on the dome flanks above the MSC bottom, which is generally folded. They also interrupt the continuity of the PQ 

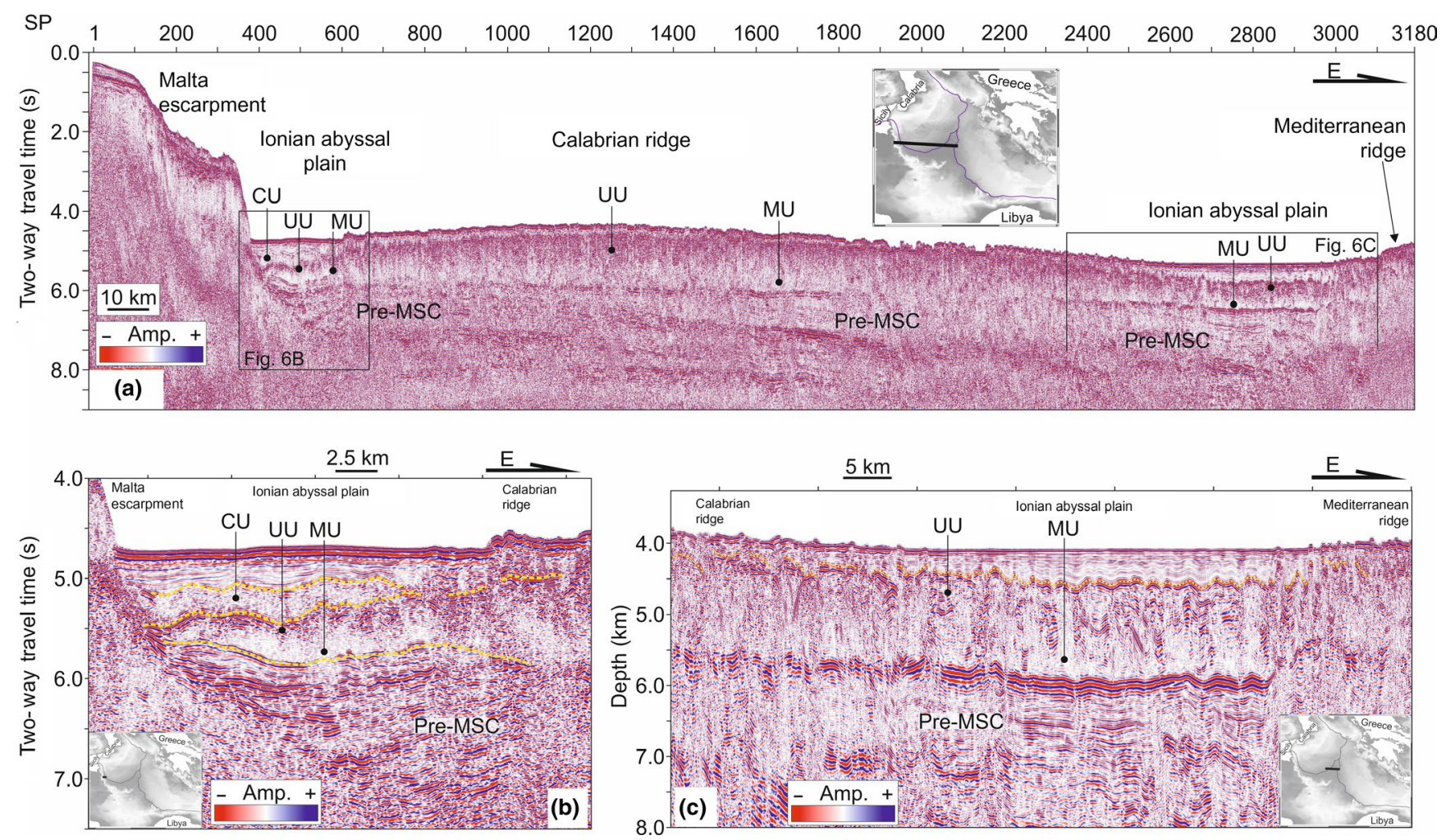

F I G URE 6 (a) Part of time-migrated profile MS-112 crossing longitudinally the outer Calabrian Ridge. Note as the compressive tectonics affects only the MSC and PQ units. The steep Malts Escarpment is onlapped by the basinal units (detail in B), including the Zanclean megaflood deposits (MFD in Figure 1b), indicated as Complex Unit, CU described by Micallef et al. (2018). (c) In the Ionian Abyssal Plain the two opposite deformation fronts of the Calabrian and Mediterranean ridges have originated a gentle deformation in MSC and PQa, $b$ apparently not affecting the youngest PQa. Note that this part (C) of the profile has been depth-migrated: vertical scale is in kilometres. The uninterpreted seismic profiles are available as Supporting information

horizons and, in some cases, outcrop at the seafloor (Medina Ridge, VHS, VHS-2).

\subsection{4 | The Calabrian and Mediterranean ridges domains}

In the vicinity of the deformation fronts, the sea bottom reflector acquires a typical irregular geometry (Figures 5-8), known in literature as "cobblestone topography" (Kastens, Breen, \& Cita, 1992), which reflects compressional deformation. The PQ units thin considerably across the accretionary complexes. Because of the shortening in the Calabrian and Mediterranean accretionary wedges, salt has accommodated regional contractional strain by thickening, so that the thickness of the MSC units imaged in our seismic sections (e.g. Figure 7a) is greater than the original thickness found in the abyssal plain.

The undulated topography of the seafloor and the sediment deformation, gradually more complex towards the inner sectors of the accretionary complexes, cause scattering of seismic energy, compromising resolution and penetration in the seismic profiles. Accordingly, identification of deep reflectors outside the rims of the abyssal plains becomes difficult or impossible.

\section{2 | Velocity analyses and units' thickness}

Given the large water depth in the Ionian Sea and the high degree of deformation all around the Ionian Abyssal Plain, reliable estimation on the seismic velocity distribution in the PQ, MSC and pre-MSC units has been obtained with the largest available offsets in seismic data on the least deformed sedimentary sequence. These two conditions are satisfied in portions of lines CROP-M2B, MS-112, MS-33 and MS-27 covering the Ionian and Sirt abyssal plains away from the Calabrian and Mediterranean ridges' deformation fronts (Figures 5a, 6b, 7a and 8a). Figure $8 \mathrm{~b}$ displays the velocity distribution obtained for PSDM of profile CROP-M2B. The velocity structure clearly shows the velocity anomaly produced by the evaporites of the MSC Unit. The upper $250 \mathrm{~m}$ of the MSC unit bears a relatively lower velocity of $3,565 \mathrm{~m} / \mathrm{s}$. The velocity of the $1,000 \mathrm{~m}$-thick lower part is $4,245 \mathrm{~m} / \mathrm{s}$. The two parts correspond nicely to seismic facies units UU and MU described above, and the velocity difference matches the lithological difference between mainly gypsum (above) and halite (below) (Dal Cin et al., 2016). There is an important variability of the velocity found in MU, with peaks of $4,950 \mathrm{~m} / \mathrm{s}$. 
F I G URE 7 (a) Part of depth-migrated profile MS-33 crossing the south-western front of the Mediterranean Ridge and the Sirt Abyssal Plain. Compressive tectonics has caused tilting and fracturing in the preMSC units and a more complex halokinesis in MSC, while the overlying PQ unit seems mainly undeformed in the abyssal plain. The uninterpreted seismic profiles are available as Supporting information. (b) South-eastern part of the time-migrated profile CROP$\mathrm{M} 2 \mathrm{~B}$ crossing the outer Calabrian Ridge. Compressional tectonics affects only the PQ and MSC units, with decreasing deformation towards the abyssal plain. The PQ unit is mainly undeformed in the abyssal plain. The deformed pre-MSC is truncated by a clearcut surface defined by salt detachment. The uninterpreted seismic profiles are available as Supporting information
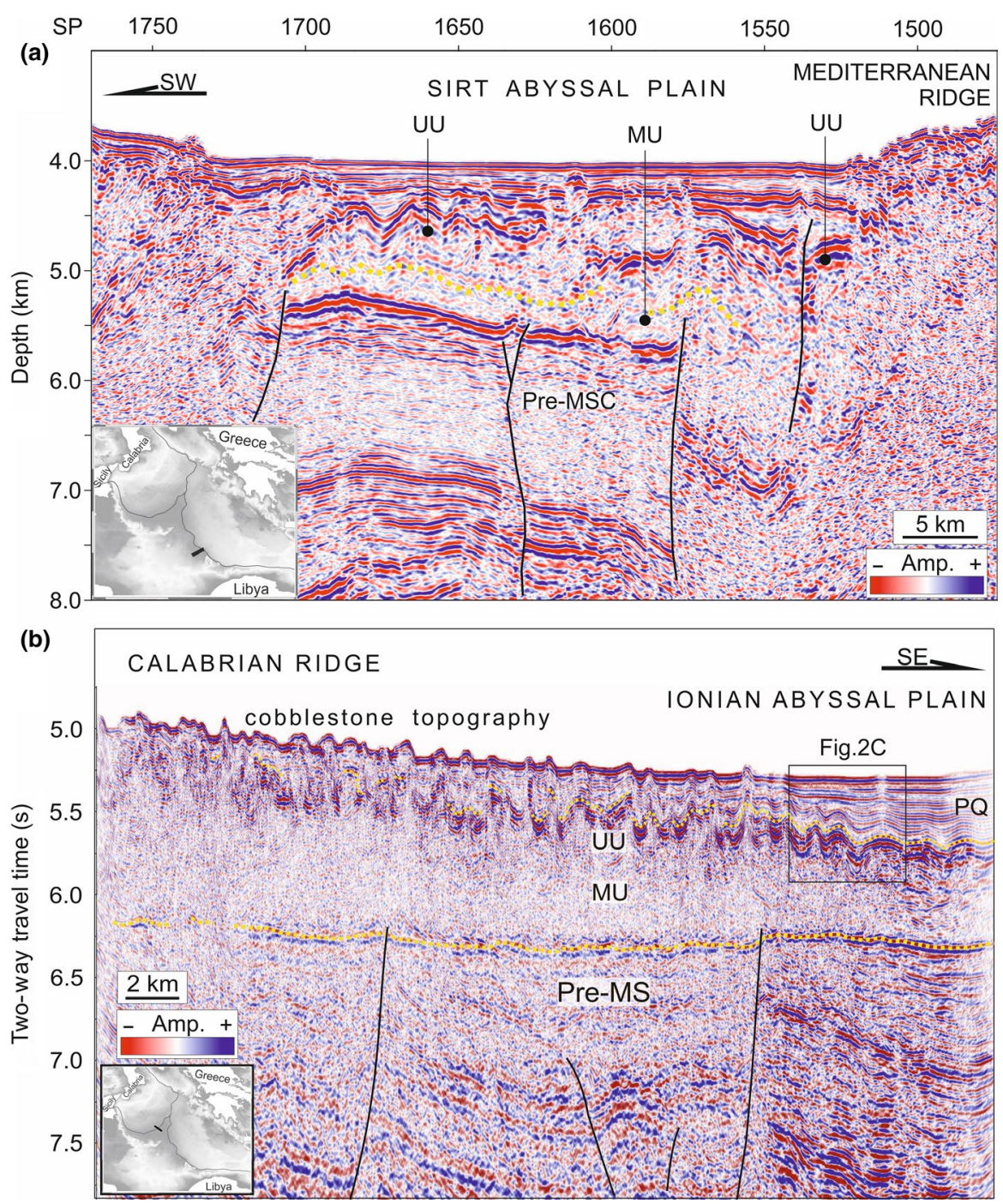

Below the MSC sequence, the velocity sharply decreases to values lower than UU, varying between 2,440 and 3,000 m/s. Extreme low-velocity values below the MSC Sequence $(2,440 \mathrm{~m} / \mathrm{s})$ could be induced by errors due to the relatively low offset compared to the depth of the target or to a degree of overpressure.

The result of the MSC sequence thickness computation is presented in Figure 9. The errors implied in the calculation may derive from velocity changes with respect to the $4,000 \mathrm{~m} / \mathrm{s}$ velocity assigned to the entire MSC sequence and to uncertainties in picking the MSC bottom reflector in the Mediterranean and Calabrian accretionary complexes, due to intense tectonic deformation. In order to provide an estimate of the sensitivity of the results to velocity changes, if real velocities vary $\pm 400 \mathrm{~m} / \mathrm{s}(3,600-4,400 \mathrm{~m} / \mathrm{s})$, the error in the volumetric calculation is $\pm 10 \%$. More challenging is the contribution of the picking. The extend of the evaporites in the Ionian basin has been variably interpreted in the literature. Some authors (e.g. Polonia et al., 2016) conservatively interpret the evaporites allowing for a large extent of pre-Messinian accretionary wedge; others (e.g. Reston, Fruehn, et al., 2002; Reston, von Huene, et al., 2002) interpret a more extensive evaporite distribution in the accretionary wedges. Our interpretation follows the latter.

\section{6 | DISCUSSION}

\subsection{MSC seismic markers in the Ionian Sea}

\subsection{1 | Regional low-resolution markers}

The analysis of a number of seismic profiles with different resolution provides evidence for a more complex seismic character of the MSC units than previously thought.

In the regional low-resolution record, the typical "trilogy" of seismic units representing the MSC deposition in the Western Mediterranean (LU-MU-UU, Lofi et al., 2011 and references therein) cannot be recognized in the Ionian Basin (Figure 10). Similarly, the other end-member seismic expression of sediment deposition during the MSC in the Levant Basin, composed of one single-layered sequence of 
(a)

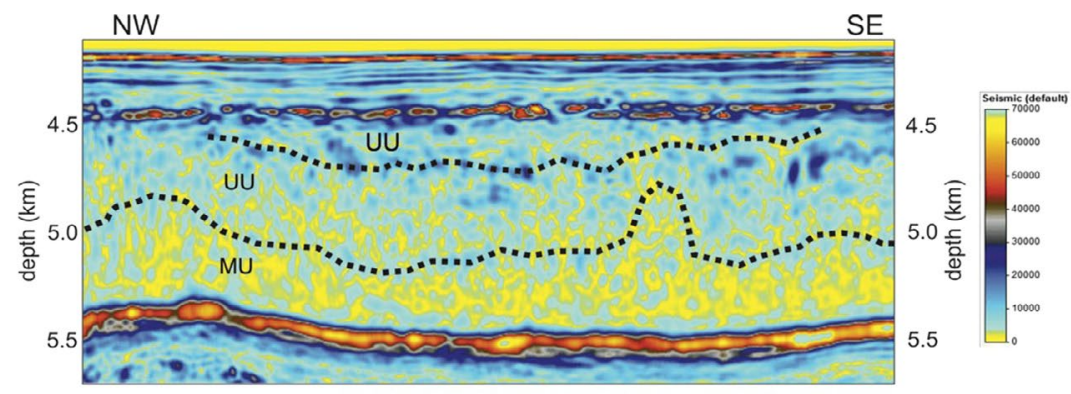

(b)

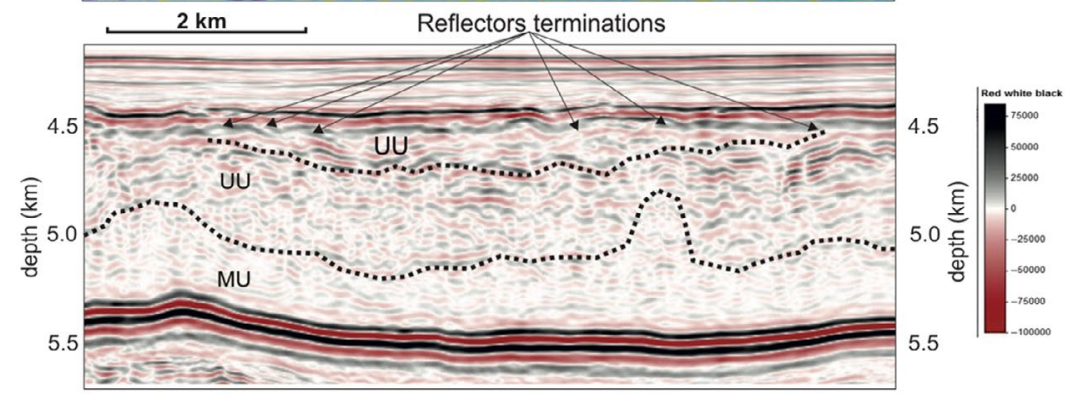

(c)

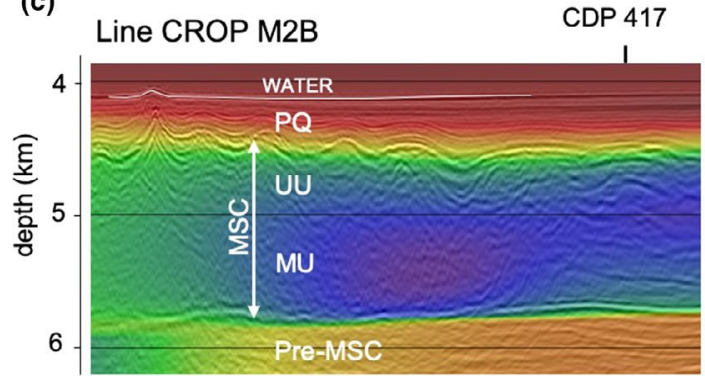

Line CROP M2B
Interval Velocity CDP 417 $\left(\mathrm{km} \mathrm{s}^{-1}\right)$

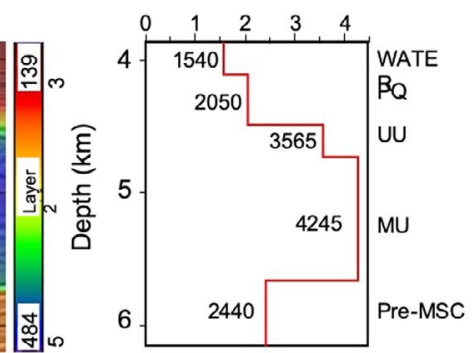

F I G URE 8 Reflection strength (a) and Relative Acoustic Impedance (b) of depth-migrated profile MS-27. Seismic attributes highlight very clearly the MSC top and bottom and contribute to distinguish between the lower, typically transparent MU and the gradual upper transition to $\mathrm{UU}$, made of discontinuous reflectors that describe a synform depocentre in its upper part. (c) Part of depth-migrated profile CROP-M2B with superimposed interval velocities in colours and velocity profile at CDP 417. The interval velocities have been obtained by performing residual velocity analysis on Common Image Gathers (CIG) analysis and used for the depth migration of the profile. Note the high interval velocity of the MU and the velocity inversion at its base. The uninterpreted seismic profiles are available as Supporting information salt units separated by high-amplitude reflections (four to six units identified by Bertoni \& Cartwright, 2006; Gvirtzman et al., 2013; Netzeband et al., 2006) cannot be recognized either. In the deep Ionian Basin, the MSC depositional unit is composed of one single $\sim 1,300$-m-thick high-velocity unit containing a sub-division in two sub-units (Figure 10):

1. An upper, 350-1,000-m-thick sub-unit characterized by high velocity compatible with UU velocity in the Western Mediterranean (3,250 m/s; Dal Cin et al., 2016), although bearing a very different internal configuration. This interval velocity is less than the lowermost velocity of $3,650 \mathrm{~m} / \mathrm{s}$ that has been calculated for the MU in the Levant Basin (Reiche, Hübscher, \& Beitz, 2014). The uppermost $80 \mathrm{~m}$ of this unit, sampled by DSDP Site 374 , is made of cycles of mudstone-gypsum and anhydrite-halite. The depocentre in UU outlined by a concave-up high reflectivity band intersecting the upper UU boundary, suggests erosion of the upper part of $\mathrm{UU}$ at its sides. In this case, the depocentRe can be interpreted as re-sedimentation of the UU eroded at the rims of the basin. The presence of two important structures in the pre-MSC units (see below), provides evidence for a link between the activity of the structures and the UU marginal erosion.

2. A lower, 150-700-m-thick transparent high-velocity subunit corresponding to the MU. Like UU, also the MU in the Ionian Basin differs from the typical Western Mediterranean MU. The upper boundary is not a sharp transition to UU, and the internal configuration is less transparent. The velocities up to $4,950 \mathrm{~m} / \mathrm{s}$ match the values proposed by Dal Cin et al. (2016) in the Western Mediterranean, and are in agreement with the halite composition of this anomalous MU. Yet, this velocity is higher than the maximum velocity of the transparent MU units in Levant Basin (Reiche et al., 2014). In a small evaporitic basin between the VHS-2 and the VHS structures (Figure 5b), the MU shows the typical roll-over deformation structure on one side as consequence of local gravity gliding or spreading (e.g. Lofi et al., 2005).

The differences in the internal reflection configurations of the MUs in the several basins are considered as less important in terms of mineral deposition, since the internal reflections of the MU in the Levant Basin are caused by intercalated clastics and not by vertically varying evaporitic facies (Feng et al., 2016). 


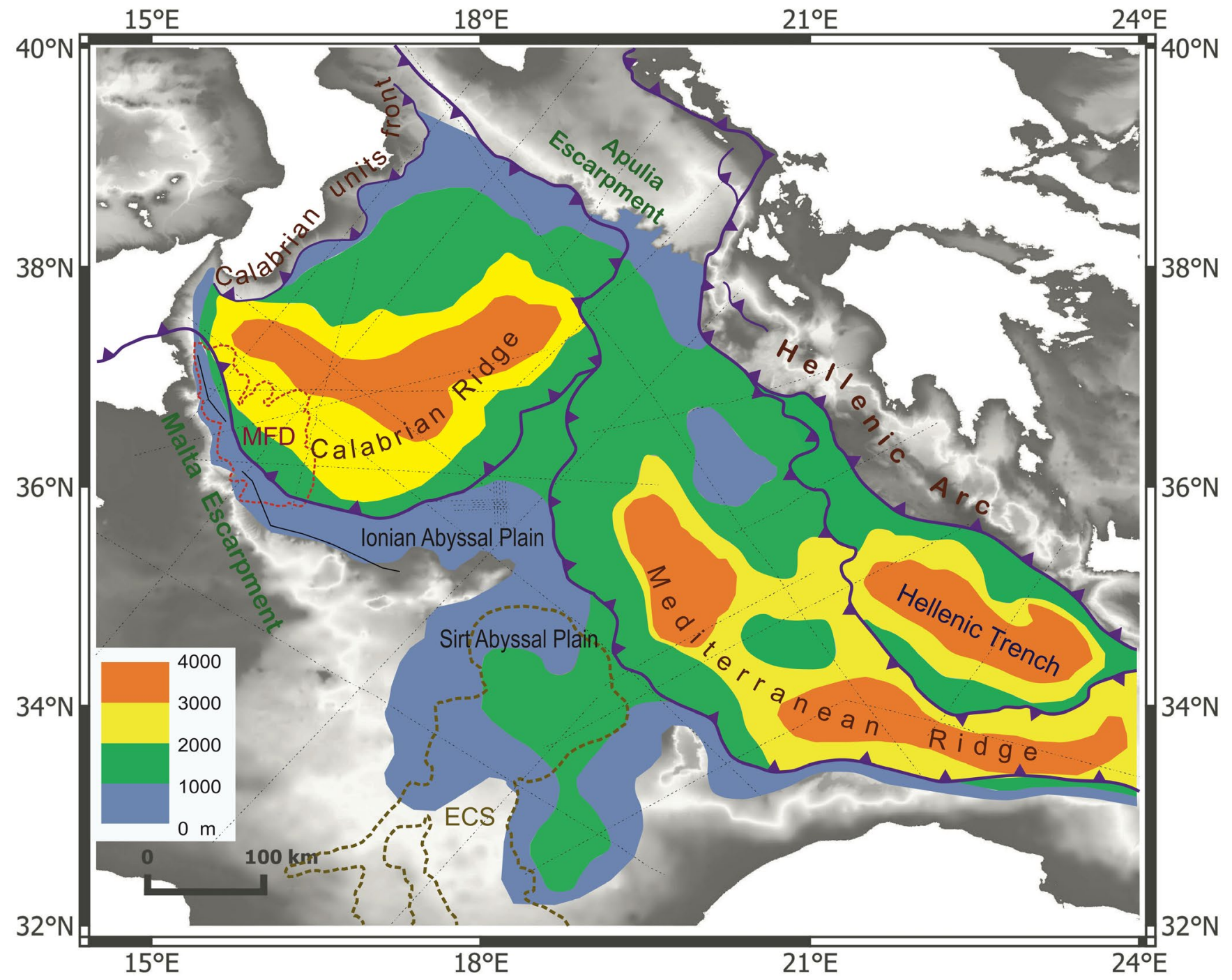

F I G URE 9 Isopach map of the MSC units in the Ionian Sea. The thickness becomes null at the foot of the Malta and Apulia escarpments, where the MSC units onlap older structures. Maximum values are reached in the Calabrian and Mediterranean ridges, due to severe duplexing, partially incorporating also pre-MSC units. Compressional tectonics in the inner front of the Mediterranean Ridge also accumulated a large MSC volume in the Hellenic Trench. Small Messinian basins, not mapped, are known to exist locally in Calabria and Greece onshore. Position of the seismic profiles and boundaries of MFD and ECS (see Figure 1b) are indicated with dashed lines. See text for discussion

We do not observe a LU sensu strictu. A thin discontinuous highly reflective unit found around pre-MSC structures (e.g. the VHS-2 structure; Figure 5b) could be interpreted as a thin modified LU in the Ionian Sea analogously to the Western Mediterranean trilogy. However, we do not have velocity information in support of this interpretation. Moreover, the pre-MU reflectors do not show the typical lateral continuity of facies that characterizes the Western Mediterranean LU.

The only evidence of a Complex Unit (CU) is the large seismically chaotic unit in the NW Ionian Basins interpreted as the result of the Zanclean MF (Micallef et al., 2018; 2019) stratigraphically placed above UU and below the PlioceneQuaternary units (CU in Figure 6a).

The clear onlap of the whole package of the MSC on preMessinian structural highs bordering to the south the Ionian
Basin (Medina Ridge and the continuing buried structure, see below; Figures 1, 4 and 5a) and to the west against the pre-existing Malta Escarpment relief (Figure 6a) suggests a closure of the Messinian evaporitic basin and a separation from the Sirt Basin beyond the Medina Ridge (Figure 5a). Such separation is supported by the different internal structure, geometry and thickness of the MSC units in the two basins: thick MSC unit with a smooth continuous lower boundary below the Ionian abyssal plain, with a transparent UU, opposed to a thin, chaotic MSC unit, with no clear separation between MU and $\mathrm{UU}$, with a rough discontinuous lower boundary in the Sirt abyssal plain. The two basins, however, were likely open and interconnected to the east of the abyssal plains, forming a wider Messinian basin now accreted in the Mediterranean Ridge accretionary prism. 


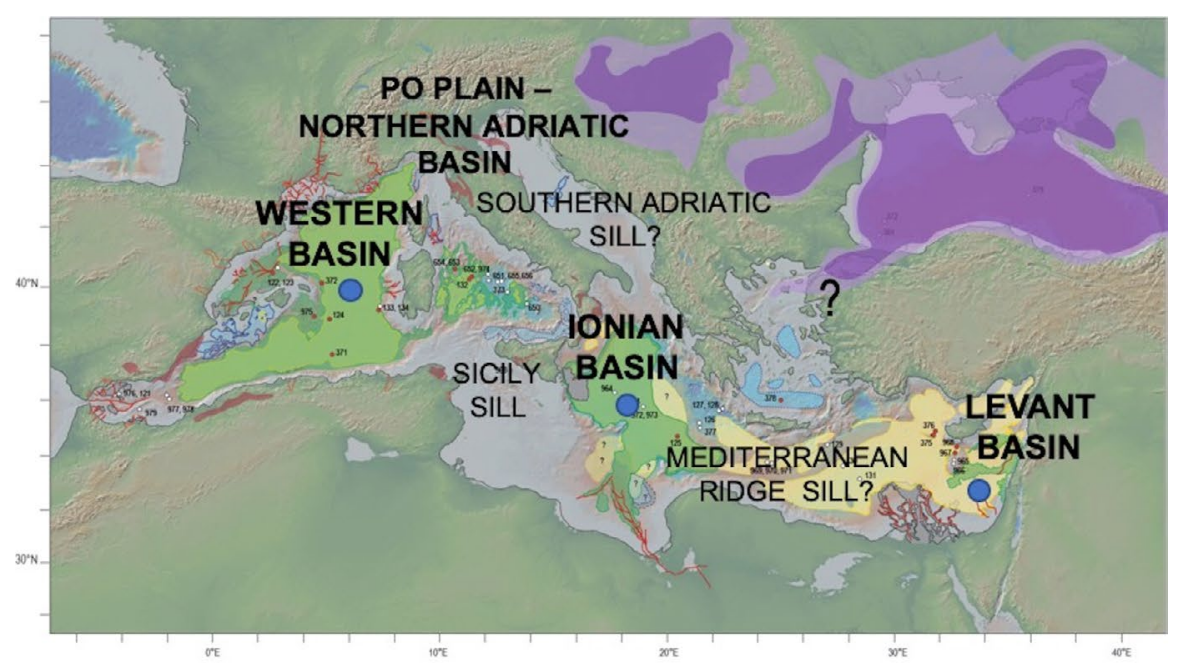

FIGURE 10 Comparison in real depth scale of the MSC seismic stratigraphy in the Western Mediterranean Basin, Ionian Basin and Levant Basin. Note that the three basins host a very different MSC stratigraphy, in terms of acoustic facies, units, thickness and depth below the present-day sea level. The map illustrates the present-day extension map of the MSC deposits (Krijgsman et al., 2010; Lofi, 2018). See text for discussion

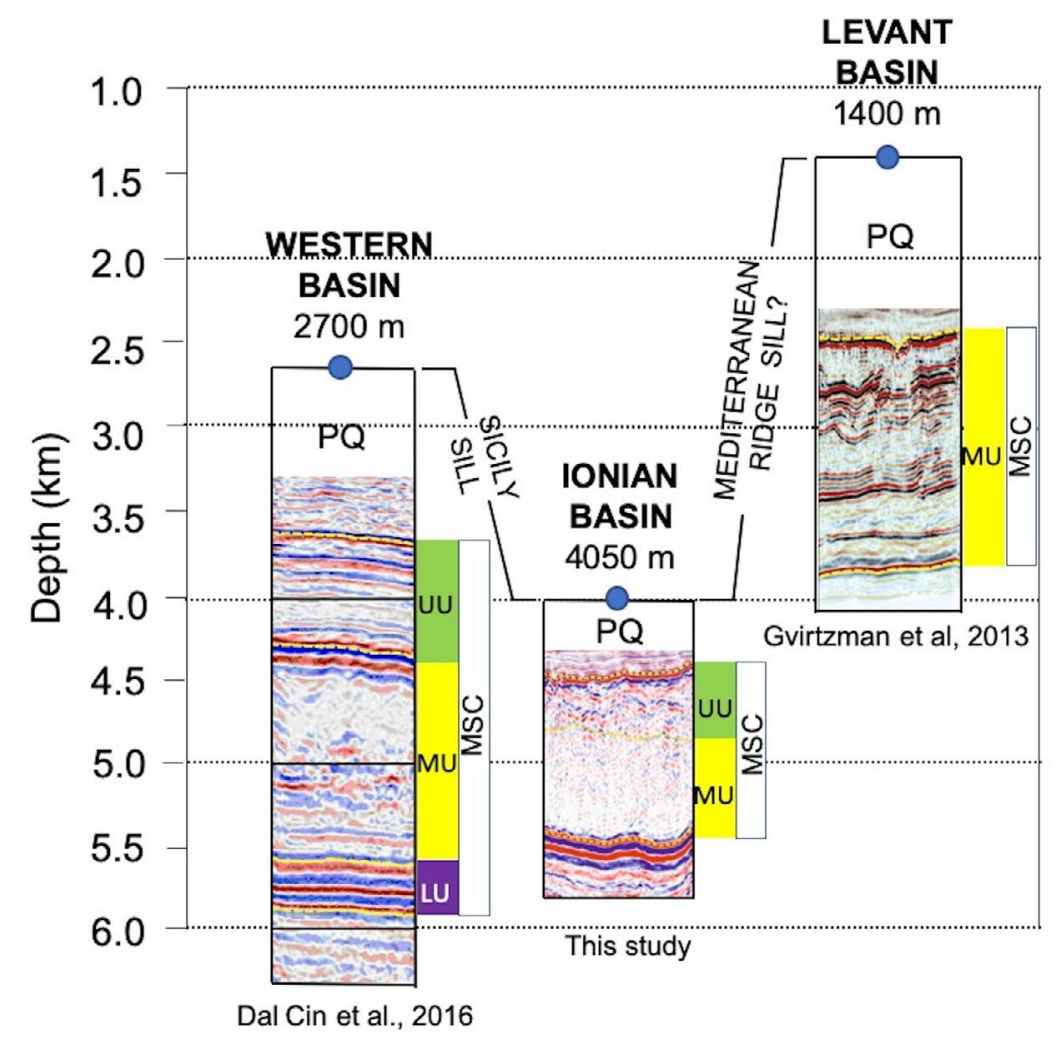

\subsection{2 | Site-specific high-resolution markers}

The high-resolution seismic imaging of the MSC depositional units shows features never reported before. The extremely irregular upper boundary of UU in the Ionian Abyssal Plain outlining in 2D V-shaped surfaces, resembles a series of incised valleys with a width of 1-2 km (Figure 4c,d) and can be interpreted as an erosional surface (TES).

The alternation of high and low reflectivity sub-units in UU (UUa, UUb, UUc) reflects the occurrence of dolomitic mudstone with gypsum, anhydrite and halite sampled in DSDP Site 374. We interpret the seismic layering as a reflection of a lithologic layering, possibly including a thin upper salt layer within the gypsum and anhydritedominated UU. Thin halite layers within UU have been identified in high-resolution seismic data on the Western Mediterranean basins (Dal Cin et al., 2016; Geletti et al., 2014).

The very different seismic expression of the MSC depositional units at the western boundary of the Ionian Basin, bordered by the Malta Escarpment (about $150 \mathrm{~m}$ of high reflectivity UU sharply separated from a 250- to 500-m-thick seismically transparent MU with a sharp basal reverse-polarity reflector filling a pre-existing surface) suggests a lateral zonation of evaporites from the deep basin depocenter to the basin margin similar to that observed in the Algero-Balearic Basin, at the foot of the Emile Baudot Escarpment, and in 
the West Sardinia Margin, at the foot of the continental slope (Figure 6 in Dal Cin et al., 2016).

\section{2 | Pre-Messinian structures in the subducting plate}

The pre-MSC record is provided solely by the low-resolution seismic profiles. The record outlines variably reflective units affected by different types of structures, evident only below the undeformed abyssal plains. They differ north and south of the Medina Ridge/VHS structures.

The pre-MSC sedimentary wedges were deposited synchronously with the activity of steep, mainly extensional faults with a superimposed tectonic inversion through pop-up structures (Gallais, Gutscher, Graindorge, Chamot-Rooke, $\&$ Klaeschen, 2011). The activity of the tectonic inversion appears to have continued also during the Messinian, as the MSC unit here is deformed with syn-depositional erosion of UU at the flanks of uplifted parts of the basin and re-sedimentation in the basin centre.

The pre-MSC units below the Medina Ridge structures is complex and poorly resolved by the seismic data (Figure 5). They have been described by Hieke et al. (2003) both as structures with a morphological evidence at the seafloor and as buried structures. They are all elongated in SW-NE direction, parallel to the main trend defined by the Medina Ridge. Figure 5a outlines the VHS structure as chaotic, VHS-2 structure as reflective, with rough layering outlining erosion on the NE flank, sealed by the MSC units, and the Medina Ridge, which is poorly imaged seismically and characterized by steep escarpments. As outlined above, these structures were clearly active in pre-Messinian time and exerted a control on the deposition of MU, while UU is found to drape VHS-2 and the two bordering Messinian basins.

\section{3 | Contraction induced by the accretionary prisms}

Deformation resulting from Africa-Europe plate convergence is evident from small-scale folding and thrusting of the MSC and the PQ units (e.g. Costa et al., 2004; Finetti \& Del Ben, 2005; Kastens et al., 1992; Maesano et al., 2017; Mocnik et al., 2018; Polonia et al., 2017; Reston, Fruehn, et al., 2002; Reston, von Huene, et al., 2002). The outer part of the Mediterranean Ridge and Calabrian accretionary complexes detaches along the ductile MSC evaporitic units, with a migration up-section from the MSC to the PQ units. Deformation in the study area is therefore postMessinian. The basal detachment of the Calabrian Ridge, coinciding with the lower boundary of $\mathrm{MU}$, is well imaged in Figures 6 and 7b. This demonstrates that the tectonic accretion in the Messinian and post-Messinian units here is superimposed on the older and deeper crustal deformation dissecting the pre-MSC units, with high-angle normal faults and related tectonic inversion entering the subduction zone (see previous section).

The sediment contraction at the front of the accretionary prisms propagates in the NE Ionian Abyssal Plain, inducing gentle undulations in the MSC sequence (Figures 6 and 7). These are conformable with deformation in the PQc sub-unit, and sedimentary wedging and gentle unconformities in PQb (Figure 4). The marker reflector that defines the end of the deformation (above which layers are horizontal and parallel to each other) in the PQ unit is identified with the base of PQa, dated $\sim 650,000$ years by extrapolation of the linear sedimentation rate calculated in DSDP Site 374 cores. In a corresponding Mid-Pleistocene time, a change in the direction of migration of the Calabrian accretionary wedge from ESE to SSE, identified in the inner parts of the wedge by Del Ben et al. (2008), focused the deformation to the western sector of the Ionian Abyssal Plain. The gentle undulations in the MSC units are evident in UU and are generally discordant with the base of MU, suggesting that the salt is accommodating the shortening, most likely induced by gravitational gliding from the two outer wedges (Figures 6 and $7 \mathrm{~b}$ ).

In the analysed dataset, there is no evidence of gravitational sliding of gypsum beds within UU as a consequence of uplifting and tilting induced by the outer Calabrian ridge deformation (Butler, Maniscalco, Sturiale, \& Grasso, 2015).

\subsection{Implications for the understanding of the MSC in the Eastern Mediterranean}

\subsection{1 | Multiple Messinian deep basins in the Mediterranean}

The finding of a new MSC seismic stratigraphy in the deep Ionian Basin reinforces the growing evidence of the existence of several different Messinian deep basins in the Mediterranean, separated by physical sills (Lofi, 2018). These are the joint the Algero-Balearic, and Sardo-Provençal Basins in the Western Mediterranean, separated by the CorsoSardinian micro-plate from the proto-Tyrrhenian Basin and by the Pelagian Sea/Sicily Channel sill from the Ionian Basin. A recent study by Amadori et al. (2018) has restored the topography of the Po Plain and Northern Adriatic, demonstrating the existence of a relatively deep (up to 1,000 m during the 800-900 $\mathrm{m}$ sea level drop) Messinian basin in this region, suggesting that the sea level varied independently from the Western and Eastern Mediterranean, and explaining the lack of halite and potassium-rich salts in the deepest depocentres of the Po Plain area and Adriatic Basins. The identification of this Messinian basin implies a physical separation from the Ionian Basin in the southern Adriatic Sea.

The seismic stratigraphy of the MSC described in this study suggests that the Messinian Ionian Basin was not only 
separated from the Western Mediterranean and the Po PlainNorthern Adriatic, but also from the Levant Basin. The nonrestored depths from the present-day sea level of the main deep Messinian basins (Figure 10) show how the Ionian Basin and the Western Mediterranean Basins are today. The base of the halite unit-MU is found at about $5.5 \mathrm{~km}$ below sea level in the Ionian Basin, compared to $3.5 \mathrm{~km}$ in the Levant Basin. The actual Messinian bathymetry is not known and depends on isostatic adjustments to the rapid salt load, the possible variation in sea level, and the long-term thermal and flexural subsidence. The 2,000 m difference between the Ionian and Levant base of salt is hardly compensated by the different crustal structure (Govers, Meijer, \& Krijgsman, 2009; Micallef et al., 2019). We infer from this simple geometrical reconstruction, that the Ionian Sea basin was deeper than the Levant Basin during the Messinian, allowing for the deposition of a larger thickness of salts. The Ionian and Levant Basins are separated today by the Mediterranean Ridge accretionary complex that reaches the shallowest point (1,600 $\mathrm{m}$ water depth) between Crete and the Cyrenaica Peninsula, extending entirely across the Mediterranean Sea, and with the outer deformation front climbing the lower African slope (e.g. Huguen, Mascle, Woodside, Zitter, \& Foucher, 2005). The evidence for any physical sill separating the Ionian and the Levant basins (if any) in Messinian time is likely hidden in the tectonically complex structure of the accretionary prism.

\subsection{2 $\quad$ Evidence for an extreme sea level lowering in the Ionian Basin?}

The high-resolution profiles show evidence of apparent Vshaped valleys at the Messinian-Zanclean boundary. These valleys are found at a depth of about $4500 \mathrm{~m}$ below the present-day sea level. Can these valleys be interpreted as resulting from subaerial erosion of the Messinian Ionian basin margin? The strongest evidence supporting Messinian subaerial erosion and fluvial drainage systems is provided by reflectivity maps of the Top Erosional Surface in 3D seismic data sets (Ghielmi, Minervini, Nini, Rogledi, \& Rossi, 2013; Madof et al., 2019; Urgeles et al., 2010; Wescott \& Boucher, 2000). The depth of incision and width of the valleys imaged in these $3 \mathrm{D}$ cubes are comparable to the one observed below the Ionian Abyssal Plain. The Messinian fluvial drainage system feeding the area of the Ionian Abyssal Plain could be the Eosahabi channel system described in the Sirt Gulf offshore subsurface (Bowman, 2012, see ECS outline of the deposit in Figure 1). The Eosahabi channel system feeds a large sedimentary lobe, Late Messinian in age, defined as "Lago Mare", terminating to the north against the Medina Ridge structural highs. Such deposit is more than $500 \mathrm{~m}$ thick, and is found along the Sirt Gulf continental slope, with V-shaped subaerial erosional channels cutting up to $100 \mathrm{~m}$ deep and in depth, up to $2 \mathrm{~km}$ wide.
Therefore, the V-shaped incisions in the Ionian Abyssal Plain could be interpreted as the distal, northward extent of the Eosahabi channel system that has by-passed the Medina Ridges to the East to feed a Messinian Ionian endorheic basin. Even taking into account the range of isostatic adjustment to salt loading and sea level variation (Govers et al., 2009; Micallef et al., 2019) the identification of a fluvial system below the Ionian Abyssal Plain would imply an extreme lowering of the Mediterranean sea level at the end of the MSC.

The presence of steep and high pre-Messinian structures along the western and southern margin of the Ionian Abyssal Plain (namely the Malta Escarpment, the Medina Ridge and the Victor Hensen structures) allows the tracking of a clear pinch out of the Messinian halite (MU) at a depth of $4.4 \mathrm{~km}$ around the VHS structure. Above this depth, the UU also pinches out on the same structures. The structural highs, instead, are free of MSC units and are covered directly by the PQ drape. This geometry of the MSC deposits can be interpreted as an additional evidence of an extreme sea level lowering in the case of a shallow-water deposition, with the deep-seated pinch out representing a paleo-shoreline of the Messinian evaporitic basin, at least at the end of the salt deposition. Alternatively, the extremely deep pinch out of the salts can be explained by very deep salt saturation surface in the case of a deepwater evaporitic sedimentation in a stratified water mass as modelled by Simon and Meijer (2017), where the upper boundary of the salt is controlled by the position of a chemocline as postulated by Gvirtzman et al. (2017) in the Levant Basin.

\subsubsection{The contribution of the Ionian Basin to the Mediterranean Messinian evaporitic budget}

In spite of the rather large spacing among the profiles and the difficulties in picking the marker horizons within the Calabrian and Mediterranean ridges, it was possible to generate a map of the MSC top and bottom reflectors and to produce the map of the total thickness (Figure 9).

The evaporites thickness is generally easily identified in the abyssal plains and in the outermost ridges, while it becomes less evident and seismically noised in the inner sectors, where the compressive stress also affects the pre-MSC units. Here, the thickness estimation is gradually more inaccurate towards the Calabrian and the Hellenic shorelines.

The minimum thickness marks the remnant margins of the old Ionian Basin to the NE, at the foot of the Apulia Escarpment, and to the west, at the foot the Malta Escarpment, where evaporites gradually thin to zero, onlapping the pre-MSC units and surrounding the Medina Ridge.

The evaporites thickness map (Figure 9) shows two areas of maximum thicknesses, locally reaching 4,000 m and corresponding to the Calabrian and Mediterranean 
accretionary wedges where compression produced iterated duplexing of evaporites, incorporating also pre-MSC units. The two maxima are separated by an area with a notable lower thickness, trending in NE-SW direction in continuity with the direction of the Medina Ridge. Below the relatively undeformed abyssal plains and the Libyan margin in the Sirt Gulf, the MSC thickness shows much less variability. The MSC thins and disappears on the Libyan margin around the Medina Ridge, on the entire western (Malta Escarpment) and eastern (Apulian Escarpment) margins. In the deep, undeformed basin, the evaporites are thicker in the central part of the Sirt Abyssal Plain, up to more than $1,500 \mathrm{~m}$, thinning towards the Medina and VHS structures. In the Ionian Abyssal Plain the thickness only locally exceeds $1,000 \mathrm{~m}$. In the NE sector of the Ionian Abyssal Plain, sandwiched between the Mediterranean Ridge and the Calabrian Ridge, the salt has thickened due to gliding from the two opposite fronts, reaching 1,500 $\mathrm{m}$ (Figures 6 and 7a). Similarly, in the Hellenic Trench between the opposite fronts of the northward verging Mediterranean Ridge and southward verging Hellenic Arc, salt tectonics led to a thickness of more than 3,000 m.

The thickness map is limited by the inner fronts of the Calabrian units and of the Hellenic Arc. Small Messinian basins, not mapped, are known to exist locally in Calabria and Greece onshore. Up to 1,270 m of Messinian salt are known to exist offshore Calabria (Floriana-1 well, ViDEPI, 2016).

Figure 9, therefore, provides a novel map of a rough Messinian evaporites volume in the Ionian Basin based on a regional grid of seismic profile and seismic velocity analysis in support to the depth conversion of the travel times. The resulting cumulative volume is $500,000 \pm 10 \% \mathrm{~km}^{3}$ and it represents a significant portion of the total Messinian Evaporites volume in the Mediterranean, commonly estimated at 2 million $\mathrm{km}^{3}$ (Ryan, 2008) or more than 1 million $\mathrm{km}^{3}$ (Roveri, Flecker, et al., 2014). This quantification allows to predict that the total volume of salts deposited in the Mediterranean during the MSC exceeds the current estimates.

\section{7 | CONCLUSIONS}

The re-analysis of deep penetration multichannel seismic reflection data and newer high-resolution multi-channel seismic reflection data in the Ionian Basin highlights new characters of deep basin evaporitic deposits that contribute to an improved understanding of the MSC.

- The typical "trilogy" of seismic units defined in the Western Mediterranean is not present in the Ionian Basin. Consequently, there are at least three recognized deep basin MSC evaporitic sequences in the Mediterranean: (a) the "trilogy" (LU, MU, UU sensu Lofi et al., 2011; Lofi,
2018) in the Western Mediterranean Basin (excluding the Alboran, Tyrrhenian and Pelagian seas), (b) an association of MU and a modified UU with no internal layering, poor or null lateral continuity of reflectors, no sharp lower boundary with MU, replaced by a gradual and irregular transition downwards to MU in the Ionian Basin and (c) a single MU unit in the Levant Basin (Feng et al., 2016).

- The different MSC depositional units suggest that the Messinian Ionian Basin was separated by physical thresholds from the Western Mediterranean (Pelagian Sea/ Sicily Channel), from the Po Plain/Northern Adriatic Basin (southern Adriatic sill) (Amadori et al., 2018), and the Levant Basin (undefined sill hidden below the Mediterranean Ridge accretionary complex between Crete and the Cyrenaica Peninsula). This likely reflects different hydrological and climatic conditions that affected the basins evaporation and salt precipitation.

- The high-resolution seismic data imaging of the deep Ionian Basin UU may suggest the presence of erosional surfaces and V-shaped valleys, supporting an extreme sea level draw down and the presence of Late Messinian (Lago Mare) fluvial deposition analogous to the Eosahabi channel system (ECS) in the Sirt Gulf. Such evidence is restricted to the Ionian Basins and needs careful consideration in further studies.

- The MSC evaporitic units in the Ionian Basin clearly onlap pre-Messinian structural highs that are evaporite free. The pinch out depth of $4.4 \mathrm{~km}$ below present-day sea level in the southern Ionian Basin (Medina Ridge structures, and Victor Hensen Seahill structures) suggests either a very deep baselevel position, or very deepwater column stratification. This depth significantly exceeds the depth of the evaporitic continental margin pinch out in the Levant Basin and provides an evidence for different MSC evolution between the Ionian and the Levant basins. The role of Messinian and postMessinian vertical crustal movements in the Ionian Basin and the origin of the pre-Messinian structures, presently unknown, deserve further detailed investigations.

- The $500,000 \mathrm{~km}^{3}$ volume of MSC evaporites calculated in the Ionian Basin, a small portion of the Mediterranean Basin, using PSDM velocity information and a regionally and consistent seismic data set, indicates that the total volume of the MSC evaporites in the whole Mediterranean Sea may be larger than the $1-2$ million $\mathrm{km}^{3}$ commonly assumed until now.

The results of this study point to the importance of dynamic topography studies to quantify the Messinian and post-Messinian vertical displacements in sedimentary basins and sills in order to understand with greater detail the Messinian paleotopography, and the modelling of the paleoclimatic and paleohydrological parameters in each Messinian basin during the MSC. This study also points to the importance of investigating the deep 
basin MSC units with high-resolution data to decipher the morphological characters useful to reconstruct the depositional environments. Finally, a rigorous approach to the mapping of the MSC units based on well-defined criteria (e.g. the Messinian seismic markers suggested by Lofi, 2018, 2011) and converted to depth using accurate velocity analyses, is fundamental to refine the salt budget of the MSC and assess the impact on the global ocean salinity.

\section{ACKNOWLEDGEMENTS}

This study is a result of scientific cooperation within COST Action CA15103 "Uncovering the Mediterranean salt giant" (MEDSALT) supported by COST (European Cooperation in Science and Technology), Marie Curie Career Integration Grant PCIG13-GA-2013-618149 (SCARP), ERC Starting Grant n677898 (MARCAN), University of Hamburg RV Meteor Expedition M142/2. The use of CROP seismic profiles has been licensed to OGS by CNR, Banca Dati CROP (www.crop.cnr.it). The authors would also like to thank Emerson Paradigm for the use of the OGS academic licenses of the Echoes and Geodepth processing software, IHS Markit for the OGS, and the University of Trieste free licenses of the Kingdom Suite interpretation software and Schlumberger for the University of Trieste academic license of the Petrel interpretation software. Processing of the M144/2 has been carried out with Schlumberger VISTA software provided to the University of Hamburg by an academic license agreement. The authors acknowledge the constructive comments provided by reviewers Sian Evans and Andrew Madof, and the journal editor Craig Magee.

\section{DATA AVAILABILITY STATEMENT}

The data that support the findings of this study are available in: MS and CUMECS data: SNAP Seismic data base of OGS (https://snap.ogs.trieste.it). CROP data: CROP Data Center, CNR ISMAR, Bologna (CNR http://www.crop.cnr.it).

\section{REFERENCES}

Amadori, C., Garcia-Castellanos, D., Toscani, G., Sternai, P., Fantoni, R., Ghielmi, M., \& Di Giulio, A. (2018). Restored topography of the Po Plain-Northern Adriatic region during the Messinian baselevel drop-Implications for the physiography and compartmentalization of the palaeo-Mediterranean basin. Basin Research, 30(6), 1247-1263.

Arsenikos, S., Frizon deLamotte, D., Chamatte-Rooke, N., Mohn, G., Bonneau, M. C., \& Blanpied, C. (2013). Mechanism and timing of tectonic inversion in Cyrenaica (Libya): Integration in the geodynamics of the East Mediterranean. Tectonophysics, 608, 319-329. https://doi.org/10.1016/j.tecto.2013.09.025

Bache, F., Popescu, S.-M., Rabineau, M., Gorini, C., Suc, J.-P., Clauzon, G., ... Çakır, Z. (2012). A two-step process for the reflooding of the
Mediterranean after the Messinian salinity crisis. Basin Research, 24, 125-153. https://doi.org/10.1111/j.1365-2117.2011.00521.x

Ben-Avraham, Z., Woodside, J., Lodolo, E., Gardosh, M., Grasso, M., Camerlenghi, A., \& Vai, G. B. (2006). Eastern Mediterranean basin systems. Geological Society, London, Memoirs, 32(1), 263-276.

Bertoni, C., \& Cartwright, J. (2006). Controls on the basinwide architecture of late Miocene (Messinian) evaporites on the Levant margin (Eastern Mediterranean). Sedimentary Geology, 188-189, 93-114.

Biju-Duval, B., Letouzey, J., \& Montadert, L. (1978). Structure and evolution of the Mediterranean basins. Initial Reports of the Deep Sea Drilling Project, 42, 951-984.

Blanc, P.-L. (2006). Improved modelling of the Messinian salinity crisis and conceptual implications. Palaeogeography, Palaeoclimatology, Palaeoecology, 238, 349-372, https://doi.org/10.1016/j. palaeo.2006.03.033

Bowman, S. A. (2012). A comprehensive review of the MSC facies and their origins in the offshore Sirt Basin. Libya. Petroleum Geoscience, 18(4), 457-469.

Brun, J.-P., Faccenna, C., Gueydan, F., Sokoutis, D., Philippon, M., Kydonakis, K., \& Gorini, C. (2016). The two-Stage Aegean extension, from localized to distributed, a result of slab rollback acceleration. Canadian Journal of Earth Sciences, 53(11), 1142-1157.

Butler, R. W. H., Maniscalco, R., Sturiale, G., \& Grasso, M. (2015). Stratigraphic variations control deformation patterns in evaporite basins: Messinian examples, onshore and offshore Sicily (Italy). Journal of the Geological Society, 172, 113-124.

Camerlenghi, A., \& Pini, G. A. (2009). Mud volcanoes, olistostromes and Argille scagliose in the Mediterranean region. Sedimentology, 56, 319-365.

Carminati, E., \& Doglioni, C. (2005). Mediterranean tectonics. Encyclopedia of Geology, 2, 135-146.

Carminati, E., Lustrino, M., \& Doglioni, C. (2012). Geodynamic evolution of the central and western Mediterranean: Tectonics vs. igneous petrology constraints. Tectonophysics, 579, 173-192. https://doi. org/10.1016/j.tecto.2012.01.026

Cipollari, P., Cosentino, D., Radeff, G., Schildgen, T. F., Faranda, C., Grossi, F., ... Echtler, H. (2013). Easternmost mediterranean evidence of the zanclean flooding event and subsequent surface uplift: Adana basin, southern turkey. Geological Society Special Publication, 372(1), 473-493. https://doi.org/10.1144/SP372.5

Costa, E., Camerlenghi, A., Polonia, A., Cooper, C., Fabretti, P., Mosconi, A., ... Wardell, N. (2004). Modeling deformation and salt tectonics in the eastern Mediterranean Ridge accretionary wedge. Geological Society of America Bulletin, 116(7-8), 880-894.

Dal Cin, M., Del Ben, A., Mocnik, A., Accaino, F., Geletti, R., Wardell, N., .. Camerlenghi, A. (2016). Seismic imaging of Late Miocene (Messinian) evaporites from Western Mediterranean back-arc basins. Petroleum Geoscience, 22, 297-308. https://doi.org/10.1144/ petgeo2015-096

Dannowski, A., Kopp, H., Klingelhoefer, F., Klaeschen, D., Gutscher, M. A., Krabbenhoeft, A., ... Klaucke, I. (2019). Ionian Abyssal Plain: A window into the Tethys oceanic lithosphere. Solid Earth, 10, 447-462. https://doi.org/10.5194/se-10-447-2019

Del Ben, A., Barnaba, C., \& Taboga, A. (2008). Strike-slip systems as the main tectonic features in the Plio-Quaternary kinematics of the Calabrian Arc. Marine Geophysical Researches, 29, 1-12. https:// doi.org/10.1007/s11001-007-9041-6

Del Ben, A., Geletti, R., \& Mocnik, A. (2010). Relation between recent tectonics and inherited Mesozoic structures of the central-southern 
Adria plate. Bollettino di Geofisica Teorica e Applicata, 51(2/3), 99-115.

Del Ben, A., Mocnik, A., Volpi, V., \& Karvelis, P. (2015). Old domains in the South Adria plate and their relationship with the West Hellenic front. Journal of Geodynamics, 89, 15-28. https://doi.org/10.1016/j. jog.2015.06-003

Dellong, D., Klingelhoefer, F., Kopp, H., Graindorge, D., Margheriti, L., Moretti, M., ... Gutscher, M. A. (2018). Crustal structure of the Ionian basin and eastern Sicily margin: Results from a wide-angle seismic survey. Journal of Geophysical Research: Solid Earth, 123, 2090-2114. https://doi.org/10.1002/2017JB015312

Do Couto, D., Popescu, S.-M., Suc, J.-P., Melinte-Dobrinescu, M. C., Barhoun, N., Gorini, C., ... Auxietre, J.-L. (2014). Lago Mare and the Messinian salinity crisis: Evidence from the Alboran Sea (S. Spain). Marine and Petroleum Geology, 52, 57-76. https://doi. org/10.1016/j.marpetgeo.2014.01.018.

Doglioni, C., Gueguen, E., Sàbat, F., \& Fernández, M. (1997). The Western Mediterranean extensional basins and the Alpine Orogen. Terra Nova, 9, 109-112.

Estrada, F., Ercilla, G., Gorini, C., Alonso, B., Vázquez, J. T., GarcíaCastellanos, D., ... Elabbassi, M. (2011). Impact of pulsed Atlantic water inflow into the Alboran Basin at the time of the Zanclean flooding. Geo-Marine Letters, 31, 361-376. https://doi.org/10.1007/ s00367-011-0249-8

Feng, Y. E., Yankelzon, A., Steinberg, J., \& Reshef, M. (2016). Lithology and characteristics of the Messinian evaporite sequence of the deep Levant Basin, eastern Mediterranean. Marine Geology, 376, 118-131. https://doi.org/10.1016/j.margeo.2016.04.004

Finetti, I., \& Del Ben, A. (1986). Geophysical study of the Tyrrhenian opening. Bollettino di Geofisica Teorica ed Applicata, 28(110), $75-155$.

Finetti, I., \& Del Ben, A. (2005). Crustal Tectono-stratigraphy of the Ionian Sea from New Integrated CROP Seismic Data. In I. Finetti (Ed.), CROP project: Deep seismic exploration of the central Mediterranean and Italy. Atlases in Geoscience 1 (pp. 519-547). Amsterdam, the Netherlands: Elsevier Science.

Finetti, I., \& Morelli, C. (1973). Geophysical exploration of the Mediterranean Sea. Bollettino di Geofisica Teorica ed Applicata, $15,263-341$.

Finetti, I. R. (Ed.). (2005). CROP project: Deep seismic exploration of the central Mediterranean and Italy. Atlases in Geoscience 1. Amsterdam, the Netherlands: Elsevier Science. 779 p, 72 plates.

Gallais, F., Gutscher, M.-A., Graindorge, D., Chamot-Rooke, N., \& Klaeschen, D. (2011). A Miocene tectonic inversion in the Ionian Sea (Central Mediterranean): evidence from multichannel seismic data. Journal of Geophysical Research, 116B, 12108. https://doi. org/10.1029/2011JB008505

Gallais, F., Graindorge, D., Gutscher, M.-A., \& Klaeschen, D. (2013). Propagation of a lithospheric tear fault (STEP) through the western boundary of the Calabrian accretionary wedge offshore eastern Sicily (Southern Italy). Tectonophysics, 602, 141-152. https://doi. org/10.1016/j.tecto.2012.12.026

Garcia-Castellanos, D., Estrada, F., Jiménez-Munt, I., Gorini, C., Fernàndez, M., Vergés, J., \& De Vicente, R. (2009). Catastrophic flood of the Mediterranean after the Messinian salinity crisis. Nature, 462, 778-781. https://doi.org/10.1038/nature08555

Garcia-Castellanos, D., \& Villaseñor, A. (2011). Messinian salinity crisis regulated by competing tectonics and erosion at the Gibraltar arc. Nature, 480, 359-363. https://doi.org/10.1038/nature10651
Geletti, R., Zgur, F., Del Ben, A., Buriola, F., Fais, S., Fedi, M., ... Pipan, M. (2014). The Messinian salinity crisis: New seismic evidence in the West-Sardinian Margin and Eastern Sardo-Provençal basin (West Mediterranean Sea). Marine Geology, 351, 76-90.

Geletti, R., Del Ben, A., Mocnik, A., \& Camerlenghi, A. (2018). -18.A\&B- Cyprus Arc. In J. Lofi (Ed.), Seismic atlas of the Messinian salinity crisis markers in the Mediterranean sea. Volume 2. - Mémoires de la Société géologique de France, n.s., 2018, t. 181, and Commission for the Geological Map of the World, pp. 63-64.

Ghielmi, M., Minervini, M., Nini, C., Rogledi, S., \& Rossi, M. (2013). Late Miocene-Middle Pleistocene sequences in the Po Plain e Northern Adriatic Sea (Italy): The stratigraphic record of modification phases affecting a complex foreland basin. Marine and Petroleum Geology, 42, 50-81.

Govers, R., Meijer, P., \& Krijgsman, W. (2009). Regional isostatic response to Messinian salinity crisis events. Tectonophysics, 463(14), 109-129.

Govers, R., \& Wortel, M. J. R. (2005). Lithosphere tearing at STEP faults: Response to edges of subduction zones. Earth and Planetary Science Letters, 236, 505-523.

Granado, P., Urgeles, R., Sàbat, F., Albert-Villanueva, E., Roca, E., Muñoz, J. A., ... Gambini, R. (2016). Geodynamical framework and hydrocarbon plays of a salt giant: The NW Mediterranean Basin. Petroleum Geology, 22, 309-321. https://doi.org/10.1144/petge o2015-084

Gutscher, M. A., Kopp, H., Krastel, S., Bohrmann, G., Garlan, T., Zaragosi, S., ... Sallares, V. (2017). Active tectonics of the Calabrian subduction revealed by new multi-beam bathymetric data and high-resolution seismic profiles in the Ionian Sea (Central Mediterranean). Earth and Planetary Science Letters, 461, 61-72.

Gvirtzman, Z., Manzi, V., Calvo, R., Gavrieli, I., Gennari, R., Lugli, S., ... Roveri, M. (2017). Intra-Messinian truncation surface in the Levant Basin explained by subaqueous dissolution. Geology, 45, 915-918. https://doi.org/10.1130/G39113.1

Gvirtzman, Z., Reshef, M., Buch-Leviatan, O., \& Ben-Avraham, Z. (2013). Intense salt deformation in the Levant Basin in the middle of the Messinian salinity crisis. Earth and Planetary Science Letters, 379, 108-119. https://doi.org/10.1016/j.epsl.2013.07.018

Hieke, W., \& Dehghani, G. A. (1999). The Victor Hensen structure in the central Ionian Sea and its relation to the Medina Ridge (Eastern Mediterranean). Zeitschrift der Deutschen Geologischen Gesellschaft, 149, 487-505.

Hieke, W., Hirschleber, H. B., \& Dehghani, G. A. (2003). The Ionian Abyssal Plain (central Mediterranean Sea): Morphology, subbottom structures and geodynamic history-An inventory. Marine Geophysical Researches, 24(3-4), 279-310.

Hsü, K. J., Montadert, L., Bernoulli, D., Bizon, G., Cita, M., Erickson, A., ... Wright, R. C. (1978). Site 374: Messina abyssal plain. In Initial reports of the Deep Sea Drilling Project (Vol. 42, Part 1). Washington, DC: U.S. Government Printing Office.

Huguen, C., Mascle, J., Woodside, J., Zitter, T., \& Foucher, J. P. (2005). Mud volcanoes and mud domes of the Central Mediterranean Ridge: Near-bottom and in situ observations. Deep-Sea Research Part I, 52, 1911-1931.

Hübscher, C., Ahlrichs, N., Blum, M., Forlin, E., Frahm, L., Grob, H., ... Raeke, A. (2018). Understanding dolomite formation, IODP pre-site survey-DOLOMITE, Cruise No. M144/2, 23 January - 10 February 2018, Catania (Italy) - Mindelo (Cape Verde). 
Gutachterpanel Forschungsschiffe. Bonn, ISSN 2195-8475. https:// doi.org/10.2312/cr_m144_2

Kastens, K. A., Breen, N. A., \& Cita, M. B. (1992). Progressive deformation of an evaporite-bearing accretionary complex. Sea-Marc1, seabeam and piston core observations from the Mediterranean Ridge. Marine Geophysical Researches, 14, 249-298.

Kokinou, E., Kamberis, E., Vafidis, A., Monopolis, D., Ananiadis, G., $\&$ Zelilidis, A. (2005). Deep seismic reflection data from offshore western Greece: A new crustal model for the Ionian Sea. Journal of Petroleum Geology, 28(2), 185-202.

Krijgsman, W., Stoica, M., Vasiliev, I., \& Popov, V. V. (2010). Rise and fall of the Paratethys Sea during the Messinian salinity crisis. Earth and Planetary Science Letters, 290, 183-191.

Krijgsman, W. (2002). The Mediterranean: Mare nostrum of earth sciences. Earth and Planetary Science Letters, 205(1), 1-12.

Lofi, J. (Ed.). (2011). Seismic atlas of the Messinian salinity crisis markers in the Mediterranean and Black seas. Volume 1. - Mémoires de la Société géologique de France, n.s., 2011, t. 179, and Commission for the Geological Map of the World.

Lofi, J. (2018). Seismic Atlas of the Messinian salinity crisis markers in the Mediterranean sea. Vollume 2 - Mémoires de la Société géologique de France, n.s., 2018, t. 181, and Commission for the Geological Map of the World, 72 p. + DVD. https://doi. org/10.10682/2018MESSINV2

Lofi, J., Sage, F., Déverchère, J., Loncke, L., Maillard, A., Gaullier, V., ... Gorini, C. (2011). Refining our knowledge of the Messinian salinity crisis records in the offshore domain through multi-site seismic analysis. Bulletin de la Société géologique de France, 182(2), 163-180.

Lofi, J., Gorini, C., Berné, S., Clauzon, G., Tadeu Dos Reis, A., Ryan, W. B. F., \& Steckler, M. S. (2005). Erosional processes and paleoenvironmental changes in the Western Gulf of Lions (SW France) during the Messinian Salinity Crisis. Marine Geology, 217, 1-30.

Loncke, L., Sellier, N., \& Mascle, J. (2011). - 12.A, B\&C- Florence Ridge and south Antalia basin. In J. Lofi (Ed.), Seismic atlas of the Messinian salinity crisis markers in the Mediterranean and Black seas. Volume 1. - Mémoires de la Société géologique de France, n.s., 2011, t. 179, and Commission for the Geological Map of the World.

Madof, A. S., Bertoni, C., \& Lofi, J. (2019). Discovery of vast fluvial deposits provides evidence for drawdown during the late Miocene Messinian salinity crisis. Geology, 47(2), 171-174. https://doi. org/10.1130/G45873.1

Madof, A. S., \& Connell, S. D. (2018). -17A, B, C- Northern Levant Basin. In J. Lofi (Ed.), Seismic Atlas of the Messinian salinity crisis markers in the Mediterranean sea. Volume 2. - Mémoires de la Société géologique de France, n.s., 2018, t. 181, and Commission for the Geological Map of the World, pp. 60-62.

Maesano, F. E., Tiberti, M. M., \& Basili, R. (2017). The Calabrian Arc: Three-dimensional modelling of the subduction interface. Scientific Reports, 7(1), 8887. https://doi.org/10.1038/s41598-017-09074-8

Mantovani, E., Viti, M., Babbucci, D., \& Albarello, D. (2007). Nubia-Eurasia kinematics: An alternative interpretation from Mediterranean and North Atlantic evidence. Annals of Geophysics, 50, 311-336.

Micallef, A., Camerlenghi, A., Garcia-Castellanos, D., Otero, D. C., Gutscher, M.-A., Barreca, G., ... Urlaub, M. (2018). Evidence of the Zanclean megaflood in the eastern Mediterranean Basin. Scientific Reports, 8, 1078. https://doi.org/10.1038/s41598-018-19446-3
Micallef, A., Camerlenghi, A., Georgiopoulou, A., Garcia-Castellanos, D., Gutscher, M.-A., Lo Iacono, C., ... Accettella, D. (2019). Geomorphic evolution of the Malta Escarpment and implications for the Messinian evaporative drawdown in the eastern Mediterranean Sea. Geomorphology, 327, 264-283. https://doi.org/10.1016/j. geomorph.2018.11.012

Mocnik, A., Del Ben, A., Camerlenghi, A., Geletti, R., \& Saule, M. (2018). - 12.B\&E- Ionian Basin. In J. Lofi (Ed.), Seismic Atlas of the Messinian salinity crisis markers in the Mediterranean sea. Volume 2. - Mémoires de la Société géologique de France, n.s., 2018, t. 181, and Commission for the Geological Map of the World, p. $41 \& 44$.

Netzeband, G. L., Hübscher, C. P., \& Gajewski, D. (2006). The structural evolution of the Messinian evaporites in the Levantine Basin. Marine Geology, 230(3-4), 249-273. https://doi.org/10.1016/j. margeo.2006.05.004

Polonia, A., Camerlenghi, A., Davey, F., \& Storti, F. (2002). Accretion, structural style and syn-contractional sedimentation in the Eastern Mediterranean Sea. Marine Geology, 186(1), 127-144.

Polonia, A., Torelli, L., Artoni, A., Carlini, M., Faccenna, C., Ferranti, L., ... Wortel, R. (2016). The Ionian and Alfeo-Etna fault zones: New segments of an evolving plate boundary in the central Mediterranean Sea? Tectonophysics, 675, 69-90. https://doi.org/10.1016/j.tecto.2016.03.016

Polonia, A., Torelli, L., Gasperini, L., Cocchi, L., Muccini, F., Bonatti, E., ... Carlini, M. (2017). Lower plate serpentinite diapirism in the Calabrian Arc subduction complex. Nature Communications, 8(1), 2172.

Reiche, S., Hübscher, C., \& Beitz, M. (2014). Fault-controlled evaporite deformation in the Levant Basin, Eastern Mediterranean. Marine Geology, 354, 53-68.

Reston, T. J., Fruehn, J., von Huene, R., \& IMERSE Working Group. (2002). The structure and evolution of the western Mediterranean Ridge. Marine Geology, 186(1), 83-110.

Reston, T. J., von Huene, R., Dickmann, T., Klaeschen, D., \& Kopp, H. (2002). Frontal accretion along the western Mediterranean Ridge: the effect of Messinian evaporites on wedge mechanics and structural style. Marine Geology, 186(1), 59-82.

Roveri, M., Flecker, R., Krijgsman, W., Lofi, J., Lugli, S., Manzi, V., ... Stoica, M. (2014). The Messinian salinity crisis: Past and future of a great challenge for marine sciences. Marine Geology, 352, 25-58. https://doi.org/10.1016/j.margeo.2014.02.002

Roveri, M., Lugli, S., Manzi, V., Gennari, R., \& Schreiber, B. C. (2014). High-resolution strontium isotope stratigraphy of the Messinian deep Mediterranean basins: Implications for marginal to central basins correlation. Marine Geology, 349, 113-125.

Ryan, W. B. F. (2008). Modeling the magnitude and timing of evaporative drawdown during the Messinian salinity crisis. Stratigraphy, 5, 227-243.

Ryan, W. B. F. (2009). Decoding the Mediterranean salinity crisis. Sedimentology, 56, 95-136. https://doi.org/10.1111/j.1365-3091.2008. 01031.x

Sàbat, F., Roca, E., Muñoz, J. A., Vergés, J., Santanach, P., \& Sans, M. (1997). Role of extension and compression in the evolution of the eastern margin of Iberia: the ESCI-Valencia trough seismic profile. Revista Sociedad Geológica de España, 8, 431-448.

Scrocca, D., Doglioni, C., Innocenti, F., Manetti, P., Mazzotti, A., Bertelli, L., ... D'Offizi, S. (Eds.). (2003). CROP Atlas-Seismic reflection profiles of the Italian crust. Memorie Descrittive della Carta Geologica d'Italia, 62, 194.

Simon, D., \& Meijer, P. T. (2017). Salinity stratification of the Mediterranean Sea during the Messinian crisis: A first model 
analysis. Earth and Planetary Science Letters, 479, 366-376. https://doi.org/10.1016/j.epsl.2017.09.045.

Speranza, F., Minelli, L., Pignatelli, A., \& Chiappini, M. (2012). The Ionian Sea: The oldest in situ ocean fragment of the world? Journal of Geophysical Research B: Solid Earth, 117(12), B12101.

Stampfli, G. M. (2005). Plate tectonics of the Apulia-Adria microplate. In I. R. Finetti (Ed.), CROP Project: Deep seismic exploration of the Central Mediterranean and Italy, Atlases in Geoscience 1 (pp. 747-766). Amsterdam, the Netherlands: Elsevier Science.

Urgeles, R., Camerlenghi, A., García-Castellanos, D., De Mol, B., Garcés, M., Verges, J., ... Hardman, M. (2010). New constraints on the Messinian sealevel drawdown from 3D seismic data of the Ebro Margin, western Mediterranean. Basin Research, 23(2), 123-145. https://doi.org/10.1111/j.1365-2117.2010.00477.x

Valenti, V. (2011). New insights from recently migrated CROP multichannel seismic data at the outermost Calabrian arc accretionary wedge (Ionian sea). Italian Journal of Geosciences, 130(3), 330-342.

Vannucci, G., Pondrelli, S., Argnani, A., Morelli, A., Gasperini, P., \& Boschi, E. (2004). An atlas of Mediterranean seismicity. Annals of Geophysics 47(1), 247-306.
ViDEPI. (2016). Retrieved from http://unmig.sviluppoeconomico.gov. it/videpi/pozzi/pozzi.asp)

Wescott, W. A., \& Boucher, P. J. (2000). Imaging submarine channels in the western Nile Delta and interpreting their paleohydraulic characteristics from 3-D seismic. The Leading Edge, 19, 580-591. https:// doi.org/10.1190/1.1438662.

\section{SUPPORTING INFORMATION}

Additional supporting information may be found online in the Supporting Information section at the end of the article.

How to cite this article: Camerlenghi A, Del Ben A, Hübscher $\mathrm{C}$, et al. Seismic markers of the Messinian salinity crisis in the deep Ionian Basin. Basin Res. 2019;00:1-23. https://doi.org/10.1111/bre.12392 